\title{
The first Ordovician cyclocystoid (Echinodermata) from Gondwana and its morphology, paleoecology, taphonomy, and paleogeography
}

\author{
Mike Reich, ${ }^{1,2,3}$ James Sprinkle, ${ }^{4}$ Bertrand Lefebvre, ${ }^{5}$ Gertrud E. Rössner, ${ }^{1,2,3}$ and Samuel Zamora ${ }^{6}$ \\ ${ }^{1}$ SNSB - Bavarian State Collection of Palaeontology and Geology, Richard-Wagner-Strasse 10, 80333 München, Germany \\ $\langle$ m.reich@1rz.uni-muenchen.de〉,〈g.roessner@1rz.uni-muenchen.de〉 \\ ${ }^{2}$ Department of Earth and Environmental Sciences, Division of Palaeontology and Geobiology, Ludwig-Maximilians-Universität München, \\ Richard-Wagner-Strasse 10, 80333 München, Germany 〈mike.reich@lmu.de〉 \\ ${ }^{3}$ GeoBio-Center, Ludwig-Maximilians-Universität München, Germany \\ ${ }^{4}$ Department of Geological Sciences, Jackson School of Geosciences, University of Texas, 1 University Station C1100, Austin, Texas \\ 78712-0254, USA 〈echino@jsg.utexas.edu〉 \\ ${ }^{5}$ UMR CNRS 5276 LGLTPE, Université Lyon 1, 2 rue Raphaël Dubois, 69622 Villeurbanne cedex, France 〈bertrand.lefebvre@univ-lyon1.fr〉 \\ ${ }^{6}$ Instituto Geológico y Minero de Espana, C/Manuel Lasala 44, 9 B, 50006 Zaragoza, Spain〈samuel@unizar.es〉
}

\begin{abstract}
Moroccodiscus smithi represents a new cyclocystoid genus and species based on moldic specimens from the Middle Ordovician Taddrist Formation (Darriwilian) of SE Morocco. This represents the earliest articulated member of the Cyclocystoidea and is the first complete cyclocystoid described from the Ordovician of Gondwana, as well as the first cyclocystoid ever recorded from Africa. The anatomy and morphology of this new species were studied using a combination of conventional paleontological methods and nondestructive X-ray computed tomography. Because Moroccodiscus differs from other cyclocystoids, in particular by lacking cupules attached to the marginal ossicles, it is assigned to the new family Moroccodiscidae. This new taxon illustrates the relatively poorly known early diversification of these enigmatic extinct echinoderms and sheds light on the mode of life of cyclocystoids, including injuries to plate circlets during early ontogeny and folding of these disk-like specimens at the time of death. The overall thecal shape was very similar in cyclocystoids and many domal edrioasteroids, probably because they were both sessile or attached, benthic, suspension feeders. However, many oral surface, ambulacral, and marginal ring features had become very different, indicating that these two groups had either converged because of similar life modes or were only distantly related sister groups.
\end{abstract}

\section{Introduction}

Cyclocystoids are a relatively small extinct class of circular, flattened echinoderms that have been known for more than 160 years. Twenty genera and about 40 valid species have been named (Reich and Kutscher, 2010; Sprinkle et al., 2015), from articulated and disarticulated material, ranging from the Middle Ordovician to the early Carboniferous (Heaslip, 1969; Smith and Paul, 1982; Ressmeyer and Frest, 1983; Berg-Madsen, 1987; Fluegeman and Orr, 1990; Haude and Thomas, 1994; Boczarowski, 2001; Sevastopulo, 2002). Most specimens come from Laurentia and Baltica (Lefebvre et al., 2013), but a few are known from Avalonia and Laurussia. Jell and Jell (1999) published the only report of a cyclocystoid plate from Gondwana (Upper Devonian of Australia). However, our new cyclocystoid material described here represents the second report (and first articulated Ordovician material) of this echinoderm group from Gondwana.

Cyclocystoid morphology has been controversial because well-preserved specimens that show all parts of the animal are rare (Paul, 1982), and several different interpretations of their morphology and life mode have been proposed (Salter and Billings, 1858;
Foerste, 1920; Sieverts-Doreck, 1951; Kesling, 1963, 1966). In addition, despite the abundance of cyclocystoids in Ordovician strata (Table 1) in comparison to the SilurianCarboniferous record, our understanding of their origin and phylogeny lags well behind that of many other echinoderm groups. Smith and Paul (1982) produced a comprehensive monograph of the class using a large number of well-preserved museum specimens and established six new genera. We agree with many of their conclusions involving systematics, biostratigraphy, morphology, diversity, phylogeny, and perhaps biogeography, but disagree with their interpretation of orientation and feeding mode.

The recent discovery of a new cyclocystoid (Moroccodiscus smithi) from the Middle Ordovician of Morocco shows somewhat different morphology and additional evidence about the likely living orientation of cyclocystoids. Here we describe the eight specimens of this new taxon that have been assembled by the authors, showing different morphology in comparison to all other known cyclocystoid species, genera, and families. Moroccodiscus smithi from the Middle Ordovician of Morocco represents the oldest articulated member of the Cyclocystoidea as well as the first record of this group from Africa. 
Table 1. Stratigraphic and geographic distribution of Ordovician cyclocystoid taxa (genera and species).

\begin{tabular}{|c|c|c|c|c|c|}
\hline Genus & Species & Age & Location & Country & Paleocontinent \\
\hline Monocycloides Berg-Madsen, 1987 & Monocycloides oelandicus Berg-Madsen, 1987 & Darriwilian & Öland & Sweden & Baltica \\
\hline $\begin{array}{l}\text { Moroccodiscus Reich, Sprinkle, } \\
\text { Lefebvre, and Zamora in } \\
\text { Reich et al., } 2017 \text { (this paper) }\end{array}$ & $\begin{array}{l}\text { Moroccodiscus smithi Reich, Sprinkle, Lefebvre, and Zamora } \\
\text { in Reich et al., } 2017 \text { (this paper) }\end{array}$ & Darriwilian & Drâa-Tafilalet & Morocco & Gondwana \\
\hline $\begin{array}{l}\text { Cyclocystoides } \\
\text { Salter and Billings, } 1858\end{array}$ & $\begin{array}{l}\text { Cyclocystoides latus Smith and Paul, } 1982 \\
\text { Cyclocystoides scammaphoris Smith and Paul, } 1982 \\
\text { Cyclocystoides scammaphoris Smith and Paul, } 1982 \\
\text { Cyclocystoides tholicos Smith and Paul, } 1982 \\
\text { Cyclocystoides sp. } \\
\text { 'Cyclocystoides' sp. } \\
\text { Cyclocystoides halli Billings in Salter and Billings, } 1858 \\
\text { 'Cyclocystoides', sp. } \\
\text { 'Cyclocystoides' sp. } \\
\text { Cyclocystoides sp. } \\
\text { 'Cyclocystoides' sp. }\end{array}$ & $\begin{array}{l}\text { Sandbian } \\
\text { Sandbian } \\
\text { Sandbian } \\
\text { Sandbian } \\
\text { Sandbian } \\
\text { Sandbian } \\
\text { Katian } \\
\text { Katian } \\
\text { Katian } \\
\text { Katian } \\
\text { Katian }\end{array}$ & $\begin{array}{l}\text { Ontario } \\
\text { Illinois } \\
\text { Wisconsin } \\
\text { Ontario } \\
\text { Oklahoma } \\
\text { Ontario } \\
\text { Ontario } \\
\text { Kentucky } \\
\text { Wyoming } \\
\text { Dalarna } \\
\text { Rapla region }\end{array}$ & $\begin{array}{l}\text { Canada } \\
\text { United States } \\
\text { United States } \\
\text { Canada } \\
\text { United States } \\
\text { Canada } \\
\text { Canada } \\
\text { United States } \\
\text { United States } \\
\text { Sweden } \\
\text { Estonia }\end{array}$ & $\begin{array}{l}\text { Laurentia } \\
\text { Laurentia } \\
\text { Laurentia } \\
\text { Laurentia } \\
\text { Laurentia } \\
\text { Laurentia } \\
\text { Laurentia } \\
\text { Laurentia } \\
\text { Laurentia } \\
\text { Baltica } \\
\text { Baltica }\end{array}$ \\
\hline $\begin{array}{l}\text { Zygocycloides } \\
\text { Smith and Paul, } 1982\end{array}$ & $\begin{array}{l}\text { Zygocycloides marstoni (Salter in Smith and Paul, 1982) } \\
\text { Zygocycloides marstoni (Salter in Smith and Paul, 1982) } \\
\text { Zygocycloides raymondi (Foerste, 1920) } \\
\text { Zygocycloides raymondi (Foerste, 1920) } \\
\text { Zygocycloides sp. } \\
\text { Zygocycloides blairi Smith and Wilson, 1995 } \\
\text { Zygocycloides magnus (Miller and Dyer, 1878) } \\
\text { Zygocycloides magnus (Miller and Dyer, 1878) } \\
\text { Zygocycloides marstoni (Salter in Smith and Paul, 1982) } \\
\text { Zygocycloides marstoni (Salter in Smith and Paul, 1982) } \\
\text { Zygocycloides marstoni (Salter in Smith and Paul, 1982) } \\
\text { Zygocycloides variabilis Smith and Paul, } 1982 \\
\text { Zygocycloides sp. }\end{array}$ & $\begin{array}{l}\text { Sandbian } \\
\text { Sandbian } \\
\text { Sandbian } \\
\text { Sandbian } \\
\text { Sandbian } \\
\text { Katian } \\
\text { Katian } \\
\text { Katian } \\
\text { Katian } \\
\text { Katian } \\
\text { Katian } \\
\text { Katian } \\
\text { Katian }\end{array}$ & $\begin{array}{l}\text { Ontario } \\
\text { Quebec } \\
\text { Ontario } \\
\text { Quebec } \\
\text { Dalarna } \\
\text { Kentucky } \\
\text { Indiana } \\
\text { Ohio } \\
\text { Ohio } \\
\text { Brabant } \\
\text { Shropshire } \\
\text { Scotland } \\
\text { Illinois }\end{array}$ & $\begin{array}{l}\text { Canada } \\
\text { Canada } \\
\text { Canada } \\
\text { Canada } \\
\text { Sweden } \\
\text { United States } \\
\text { United States } \\
\text { United States } \\
\text { United States } \\
\text { Belgium } \\
\text { United Kingdom } \\
\text { United Kingdom } \\
\text { United States }\end{array}$ & $\begin{array}{l}\text { Laurentia } \\
\text { Laurentia } \\
\text { Laurentia } \\
\text { Laurentia } \\
\text { Baltica } \\
\text { Laurentia } \\
\text { Laurentia } \\
\text { Laurentia } \\
\text { Laurentia } \\
\text { Avalonia } \\
\text { Avalonia } \\
\text { Laurentia } \\
\text { Laurentia }\end{array}$ \\
\hline $\begin{array}{l}\text { Apycnodiscus } \\
\text { Smith and Paul, } 1982\end{array}$ & $\begin{array}{l}\text { Apycnodiscus decussatum (Begg, 1934) } \\
\text { Apycnodiscus salteri (Hall, 1866) } \\
\text { Apycnodiscus salteri (Hall, 1866) }\end{array}$ & $\begin{array}{l}\text { Katian } \\
\text { Katian } \\
\text { Katian }\end{array}$ & $\begin{array}{l}\text { Scotland } \\
\text { Michigan } \\
\text { New York }\end{array}$ & $\begin{array}{l}\text { United Kingdom } \\
\text { United States } \\
\text { United States }\end{array}$ & $\begin{array}{l}\text { Laurentia } \\
\text { Laurentia } \\
\text { Laurentia }\end{array}$ \\
\hline Diastocycloides Smith and Paul, 1982 & Diastocycloides nitidus (Faber, 1886) & Katian & Ohio & United States & Laurentia \\
\hline Narrawayella Foerste, 1920 & Narrawayella cincinnatiensis (Miller and Faber, 1892) & Katian & Ohio & United States & Laurentia \\
\hline $\begin{array}{l}\text { Nicholsodiscus Glass, Ausich, } \\
\text { and Copper, } 2003\end{array}$ & Nicholsodiscus anticostiensis Glass, Ausich, and Copper, 2003 & Katian & Quebec & Canada & Laurentia \\
\hline $\begin{array}{l}\text { Polytryphocycloides } \\
\text { Smith and Paul, } 1982\end{array}$ & $\begin{array}{l}\text { Polytryphocycloides billingsi (Wilson, 1946) } \\
\text { Polytryphocycloides depressus (Billings in Salter and Billings, 1858) } \\
\text { Polytryphocycloides depressus (Billings in Salter and Billings, 1858) } \\
\text { Polytryphocycloides huronensis (Billings, 1865) }\end{array}$ & $\begin{array}{l}\text { Katian } \\
\text { Katian } \\
\text { Katian } \\
\text { Katian }\end{array}$ & $\begin{array}{l}\text { Ontario } \\
\text { Ontario } \\
\text { Kentucky } \\
\text { Ontario }\end{array}$ & $\begin{array}{l}\text { Canada } \\
\text { Canada } \\
\text { United States } \\
\text { Canada }\end{array}$ & $\begin{array}{l}\text { Laurentia } \\
\text { Laurentia } \\
\text { Laurentia } \\
\text { Laurentia }\end{array}$ \\
\hline $\begin{array}{l}\text { Scotiadiscus } \\
\text { Reich and Smith, } 2008\end{array}$ & $\begin{array}{l}\text { Scotiadiscus wrighti (Begg, 1940) } \\
\text { Scotiadiscus wrighti (Begg, 1940) }\end{array}$ & $\begin{array}{l}\text { Katian } \\
\text { Katian }\end{array}$ & $\begin{array}{l}\text { Scotland } \\
\text { Oslo region }\end{array}$ & $\begin{array}{l}\text { United Kingdom } \\
\text { Norway }\end{array}$ & $\begin{array}{l}\text { Laurentia } \\
\text { Baltica }\end{array}$ \\
\hline
\end{tabular}




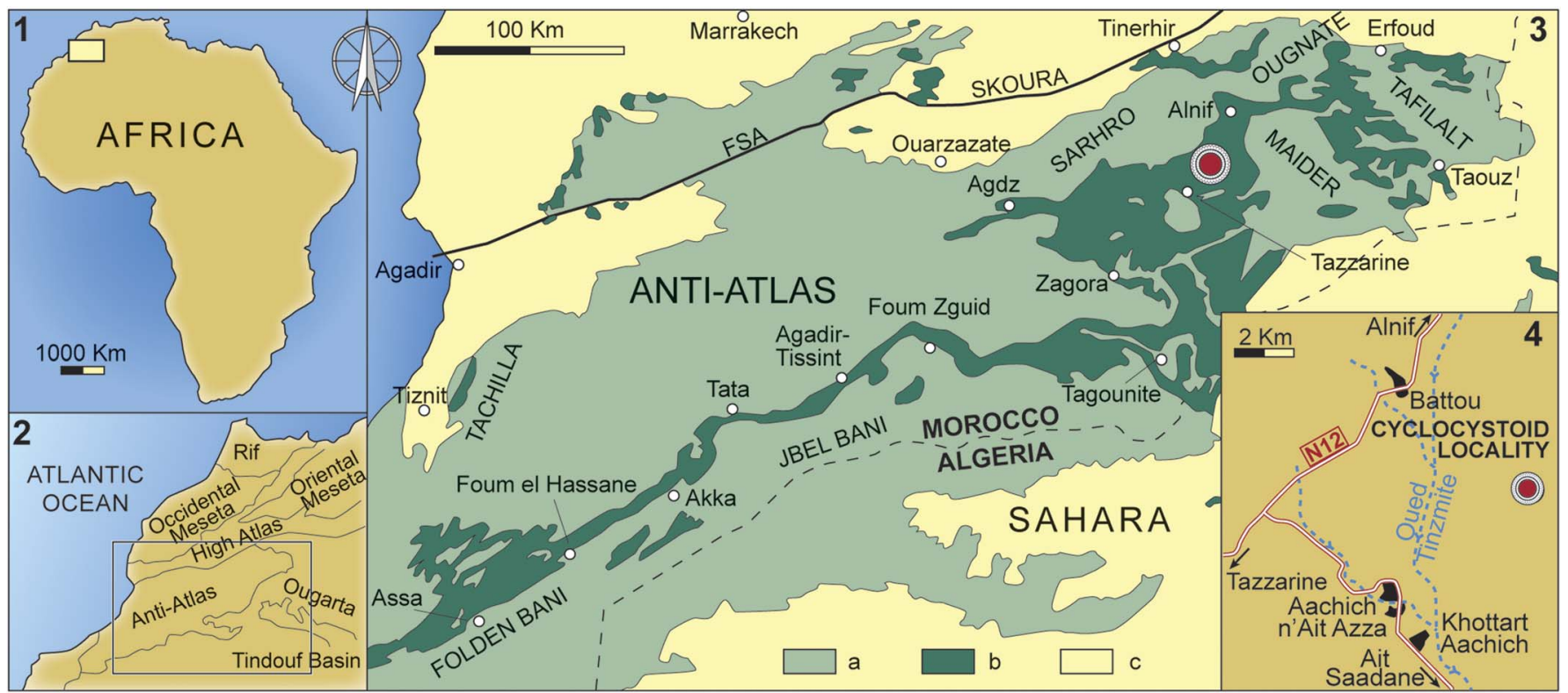

Figure 1. Geographic and geologic setting of eastern Anti-Atlas Mountains, Morocco, showing type locality of our new cyclocystoid close to the village of Battou. (1) Map of Africa. (2) Detailed map of northwest Africa showing position of Anti-Atlas Mountains. (3) Simplified geological map of Morocco with position of the cyclocystoid locality: (a) Precambrian and Paleozoic rocks; (b) Ordovician rocks; (c) post-Paleozoic cover. (4) Detailed geographic map indicating location of the cyclocystoid locality (after Rábano et al., 2014, modified).

\section{Geological setting and stratigraphy}

The Ordovician succession is particularly thick and well exposed in the Anti-Atlas Mountains of southern Morocco (Destombes et al., 1985; Fig. 1). It is traditionally subdivided into four main lithostratigraphic units: the Outer Feijas Group; the First Bani Group; the Ktaoua Group; and the Second Bani Group (Choubert, 1942; Choubert and Termier, 1947; Destombes, 1971; Destombes et al., 1985; Marante, 2008).

The Outer Feijas Group includes the Lower and Upper Fezouata formations (Tremadocian-Floian), the Zini Formation (late Floian), and the Tachilla Formation (Darriwilian) (Fig. 2). The Zini Formation corresponds to a diachronistic facies consisting of sandstones and massive quartzites, which is laterally equivalent to part of the Upper Fezouata Formation (Destombes, 1962, 1971; Destombes et al., 1985). The Zini Formation is absent in the western Maïder area (Tazzarine-Alnif area), where the cyclocystoids were collected. The three other units belonging to the Outer Feijas Group are characterized by fine-grained siliciclastic deposits (shales, siltstones), with some thin sandstone interbeds (Destombes, 1962, 1971; Destombes et al., 1985). In the Zagora area (central Anti-Atlas), the Lower and Upper Fezouata formations have yielded exceptionally preserved Burgess Shale-type faunas including anomalocaridids, demosponges, and marrellomorphs (Fezouata Biota; Botting, 2007; Van Roy et al., 2010, 2015; Lefebvre et al., 2016a; Martin et al., 2016).

The overlying First Bani Group (Darriwilian-earliest Sandbian) is the thickest, most constant, and most extensive sandstone group in the Anti-Atlas (Choubert, 1942; Destombes, 1971; Destombes et al., 1985). It is subdivided into five sandstone units with interbedded shales: the Taddrist, Bou-Zeroual, Guezzart, Ouine-Inirne, and Izegguirene formations (Fig. 2). The biostratigraphy and fossil taxa recovered from the First Bani Group were both thoroughly reviewed by Gutiérrez-Marco et al. (2003), while its sedimentology and sequential stratigraphy were investigated by Marante (2008). In the eastern Anti-Atlas, the uppermost part of the First Bani Group has yielded exceptionally preserved assemblages comprising cheloniellid arthropods, eldonioids, and palaeoscolecid worms (Tafilalt Biota; Samuelsson et al., 2001; Alessandrello and Bracchi, 2003; Van Roy, 2006; Lefebvre et al., 2008; GutiérrezMarco and Garcia-Bellido, 2015).

The First Bani Group is conformably overlain by the Ktaoua Group (Sandbian-Katian), which is predominantly composed of siltstones, with a variable number of interbedded sandstone units (Destombes, 1962, 1971; Destombes et al., 1985). It is traditionally subdivided into the Lower Ktaoua (early Sandbian-early Katian), Upper Tiouririne (middle Katian), and Upper Ktaoua (late Katian) formations (Fig. 2). Several occurrences of exceptional preservation have been reported from various levels of the Ktaoua Group, including fully articulated specimens of machaeridian annelids (Vinther et al., 2008) and dense beds of exquisitely preserved echinoderms (Hunter et al., 2010; Lefebvre et al., 2010).

In the Anti-Atlas, the Ordovician succession is topped by the sandstones of the Second Bani Group (Hirnantian), which is generally subdivided into the Lower and Upper Second Bani formations (Destombes, 1971; Destombes et al., 1985; Loi et al., 2010). The Lower Second Bani Formation corresponds to shallow shelf deposits lying conformably over the underlying Upper Ktaoua Formation (Destombes et al., 1985; Loi et al., 2010). The Upper Second Bani Formation represents fluvioglacial sandstones filling large subglacial tunnel valleys, more or less deeply excavated through the underlying deposits of the Ktaoua and First Bani groups (Destombes et al., 1985; Le Héron, 2007; Loi et al., 2010).

Echinoderm remains were first reported in the Ordovician succession of the Anti-Atlas by Ségaud and Termier (1933), 


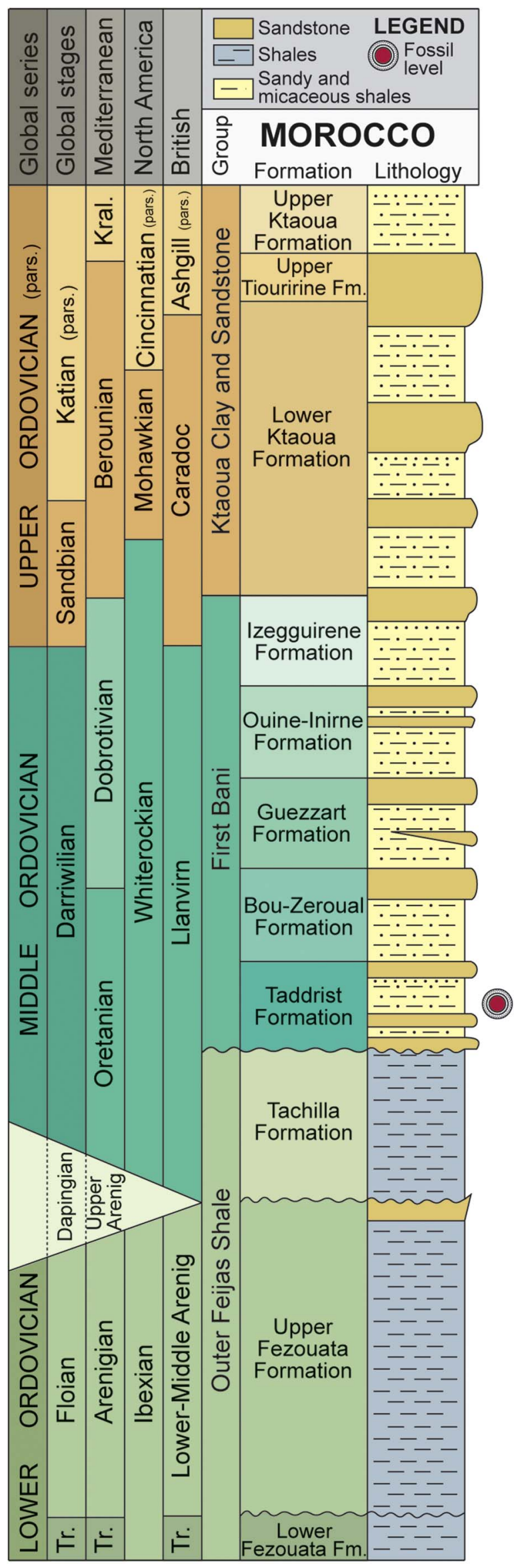

who mentioned the presence of diploporitans (Calix sedgwicki Rouault, 1851 and Holocystites? sp.) in Darriwilian quartzites from the Jbel Tachilla (western Anti-Atlas). Since this initial report, abundant and diverse echinoderm faunas have been described from various parts of the Anti-Atlas and from all Ordovician formations (Termier and Termier, 1950, 1970; Choubert et al., 1953; Ubaghs, 1963; Chauvel, 1966, 1969, 1971a, 1971b, 1977, 1978; Chauvel and Régnault, 1986; Donovan and Savill, 1988; Cripps, 1990; Beisswenger, 1994; Le Menn and Spjeldnaes, 1996; Ruta, 1999; Gutiérrez-Marco et al., 2003; Lefebvre and Fatka, 2003; Lefebvre and Botting, 2007; Lefebvre et al., 2007, 2008, 2010, 2016b; Nardin, 2007; Régnault, 2007; Hunter et al., 2010; Noailles et al., 2010; Sumrall and Zamora, 2011; Allaire et al., 2015; Martin et al., 2015; Nardin and Régnault, 2015; Sprinkle et al., 2015; Zamora et al., 2015).

As a result, the Anti-Atlas of Morocco is the only periGondwanan region yielding a relatively complete record of successive echinoderm faunas from the Tremadocian to the Hirnantian (Lefebvre et al., 2013). It thus provides a unique record of the diversification of this clade of marine invertebrates in siliciclastic settings at high, southern paleolatitudes (close to the South Pole) during the Great Ordovician Biodiversification Event (Lefebvre, 2007; Lefebvre et al., 2013). Twelve classes or distinctive groups of echinoderms have been documented so far in the Ordovician of the Anti-Atlas, including asteroids, coronates, crinoids, cyclocystoids, diploporitans, edrioasteroids, eocrinoids, ophiuroids, rhombiferans, solutans, somasteroids, and stylophorans.

The locality yielding the new cyclocystoid lies in the Taddrist Formation, close to the village of Battou (South of Alnif, eastern Anti-Atlas) (Figs. 1, 2). This locality was described by Rábano et al. (2014), who provided detailed information about the faunal content and age based on the presence of key graptolites and trilobites. In this area, the Taddrist Formation has been excavated predominantly by local collectors and has yielded a rich faunal assemblage preserved in carbonate concretions. Only three specimens of cyclocystoids were collected by us directly from the outcrop; the remainder were acquired from amateur or commercial collectors or bought at fossil shows (e.g., Sprinkle et al., 2015). Considering that the concretions from this bed between 38 and $40 \mathrm{~m}$ above the base of the formation have a characteristic aspect, all of them probably derive from the same or a laterally equivalent outcrop, and major differences in their stratigraphic position are not likely. Unfortunately, original top or bottom of our cyclocystoid concretions from this layer has not been recorded by any of the collectors, perhaps because many concretions were already weathered out and lying on the surface of this sloping outcrop.

Rábano et al. (2014) suggested that the levels containing fossiliferous concretions belong to the Didymograptus murchisoni graptolite Biozone (Gutiérrez-Marco et al., 2003), which

Figure 2. Chronostratigraphical chart for the Ordovician, indicating the level that provided the studied specimens. Correlations between stratigraphic units in the Anti-Atlas (after Destombes et al., 1985; Gutiérrez-Marco et al., 2003; Villas et al., 2006), British regional time scale (Fortey et al., 1995), North American graptolite zonal sequences (Webby et al., 2004), Mediterranean regional stages (GutiérrezMarco et al., 2003), and global stages are shown (from Sumrall and Zamora, 2011, modified). Kral $=$ Kralodvorian; Tr. $=$ Tremadocian; pars. $=$ partial. 
ranges from the late middle Darriwilian (Dw2) to the early late Darriwilian (Dw3) stage slices of the global chronostratigraphic scale (Gutiérrez-Marco et al., 2008; Bergström et al., 2009). However, the Taddrist Formation also yielded palynomorphs typical of the Laufeldochitina clavata chitinozoan Biozone (Marante, 2008; Videt et al., 2010). The stratigraphic range of this biozone is generally considered to be restricted to the base of the late Darriwilian (Dw3) stage slice (Videt et al., 2010; Gendry et al., 2013). Consequently, both graptolites and chitinozoans provide congruent stratigraphic data, supporting an early late Darriwilian age (base of Dw3) for the cyclocystoid level (Fig. 2).

The Taddrist Formation is about 80 meters thick in the western Maïder area (Tazzarine-Alnif area; Marante, 2008; Destombes, 2006). This unit was interpreted as the regressive part of a fourth-order sequence (Marante, 2008). The regressive trend was deduced from the transition from fine shales to bioturbated siltstones and finally bioturbated fine sandstones at the top of the Taddrist Formation. Sedimentary structures indicate the influence of distal storms in an otherwise relatively calm, distal setting, on an almost flat and wide continental shelf.

According to Rábano et al. (2014, p. 367), the fossiliferous concretions have yielded the trilobites Caudillaenus nicolasi Rábano et al., 2014, Morgatia? rochi (Destombes, 1972), Placoparia (Coplacoparia) n. sp., Colpocoryphe sp., Parabarrandia aff. crassa (Barrande, 1872), and an undetermined cheirurid (Eccoptochile? sp.). Other non-trilobite fossils include palynomorphs, mollusks (e.g., a cyrtonellid tergomyan, bivalves such as Praenucula sp., and orthoconic nautiloids), hyolithids (Elegantilites sp.), echinoderms (Diploporita and Asterozoa indet.), conulariids (Exoconularia sp.), and rare graptolites (Didymograptus sp.). The sandy shales above and below the fossiliferous trench contain abundant trace fossils such as Teichichnus isp. and Palaeophycus isp. In addition to the new cyclocystoid described herein, a new crinoid species, Iocrinus africanus, was recently described by Zamora et al. (2015).

The occurrence of putative remains of cyclocystoids in the early Sandbian Izegguirène Formation (Late Ordovician) of the eastern Anti-Atlas was mentioned by Lefebvre et al. (2008, 2010, 2013). This report was based on a single specimen, then belonging to the private collection of Laurent Lacombe that is now registered and deposited in the University Lyon 1 collections as UCBL-FSL 712001. However, more precise information obtained in late 2013 from Laurent Lacombe and Patrick Catto (who together collected this specimen and another one, UCBL-FSL 712000, in the mid 2000s) did not confirm this age and geographic origin, but pointed out that the two specimens were indeed collected from the same locality (Battou) and level (Taddrist Formation) described in Rábano et al. (2014).

\section{Preservation and taphonomy}

Most of the known specimens of this new cyclocystoid were preserved in siderite-encrusted (iron carbonate) concretions (Figs. 3.3-3.15, 4, 5) with a fine clastic internal matrix (siltstone?). The concretions probably formed around the specimens during early diagenesis because of decay of soft tissues and movement of $\mathrm{Fe}$ and $\mathrm{CO}_{3}$ ions through the porous matrix. At least one specimen (Fig. 3.1, 3.2; UCBL-FSL 712001) was found on a slab with similar matrix that may have been a hardground. Both occurrences probably represent repeated storm or slump deposits that buried the specimens alive in a clastic seafloor environment that was near storm wave base on a deep shelf in high-latitude Gondwana.

Many of our cyclocystoid specimens are slightly to moderately damaged, including injuries that occurred during life, damage from catastrophic events that killed, partly or completely buried, and eventually entombed them in their siderite concretions, or damage that occurred during present-day weathering or when the exposed or dug-up concretions were split open. A few specimens, such as our very large holotype (Fig. 3.1, 3.2), are complete and very well preserved, except for some loss of detail because of weathering or later casting on the inferred top mold surface, and some loss of the outer fringe region on the bottom mold that extends to the edge of its smaller slab. Another paratype is nearly complete but may be upside down in its concretion, which apparently occurred at the time of death. Other nearly complete specimens show small or large stunted areas in their marginal rings (Fig. 4.1, 4.2, 4.6, 4.7), probably from nonlethal injuries or predation during life. Others are missing parts of their ossicle ring, frontal plates, and peripheral fringe from breakage when they were killed, or disarticulated plates are strewn over the adjacent mold surface because the carcass was lying partly exposed on the seafloor. Two paratypes are mostly complete and fairly well preserved but folded over in their concretions, with their top and bottom mold layers nearly superimposed (Figs. 3.5, 3.6, 3.12, 3.13, 4.3-4.5), probably because of high currents or seafloor slumps that tumbled and perhaps broke these folded specimens. Many additional specimens in concretions are poorly preserved or incomplete (e.g., Fig. 3.10, 3.11, 3.14, 3.15). This may have occurred at the time of death, during diagenetic concretion growth, during recent weathering, or when the concretions broke up while being split open and not all the mold pieces were recovered.

\section{Materials and methods}

Specimens, repositories, and institutional abbreviations.About 20 specimens of this new cyclocystoid from the Ordovician of SE Morocco are known; this study is based on eight type specimens (and their casts; Fig. 3.1-3.15) now housed at the Collections de Paléontologie, Laboratoire de Géologie, Lyon 1 University, Villeurbanne, France (UCBL-FSL), the Natural History Museum, London, U.K. (NHMUK), the Non-vertebrate Paleontology Laboratory, University of Texas, Austin, USA (NPL), and the Bavarian State Collection of Palaeontology and Geology, Munich, Germany (SNSB-BSPG). These cyclocystoids were collected during several field campaigns (NHMUK-EE 15409, 15413, 16220), donated (UCBLFSL 712000, 712001; NPL 74385, 74386), or purchased (NPL 62451). The materials we have assembled for this study (holotype, seven paratypes, and additional photographed specimens) are listed with abbreviated stratigraphic locality information. 


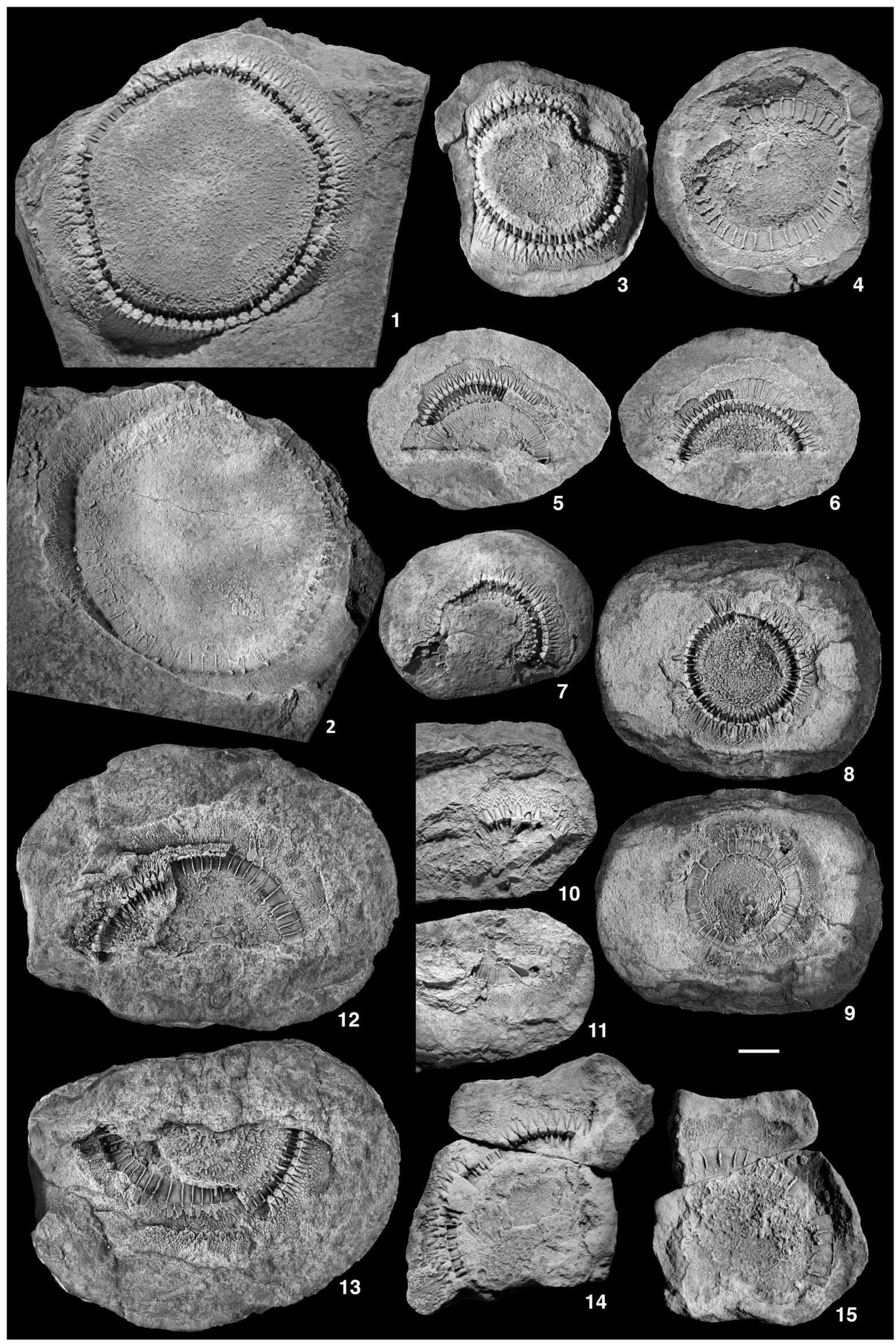


Specimen \#1, UCBL-FSL 712001, top and bottom counterpart molds on slabs (Fig. 3.1, 3.2), region of Taichoute, central Anti-Atlas, Morocco-'First Bani Group,' Darriwilian; coll. Patrick Catto (collected in the mid-2000s; donated November 2013); specimen \#2, UCBL-FSL 712000, top and bottom counterpart molds in concretion (Fig. 3.3, 3.4), region of Taichoute, central Anti-Atlas, Morocco-'First Bani Group,' Darriwilian; coll. Patrick Catto (collected in the mid-2000s, donated November 2013; specimen \#3, NPL 62451, top and bottom counterpart molds in concretion (Fig. 3.8, 3.9), same trilobite trench locality as mentioned in NHMUK specimens, listed as Oumjrane, NE of Zagora, SE Morocco $\left(30.639525^{\circ} \mathrm{N}\right.$, $005.104275^{\circ} \mathrm{W}$ ) - Darriwilian; purchased by James Sprinkle from Moussa Minerals \& Fossils at Tucson Fossil Show (February 14, 2014); specimen \#4, NPL 74385, top and bottom folded counterpart molds in concretion (Fig. 3.5, 3.6), same trilobite trench locality as mentioned in NHMUK specimens, listed as $4.8 \mathrm{~km} \mathrm{SE}$ of road N12 at Battou, SE Morocco $\left(30.55223^{\circ} \mathrm{N}, 005.15240^{\circ} \mathrm{W}\right)$-Darriwilian; donated by Kraig Derstler (April 9, 2016), who purchased it online in January 2014; specimen \#5, NPL 74386, top and bottom folded counterpart molds in concretion (Fig. 3.12, 3.13), same trilobite trench locality as mentioned in NHMUK specimens, listed as $4.8 \mathrm{~km} \mathrm{SE}$ of road N12 at Battou, SE Morocco $\left(30.55223^{\circ} \mathrm{N}\right.$, $005.15240^{\circ} \mathrm{W}$ ) - Darriwilian; donated by Kraig Derstler (April 9 , 2016), who purchased it online in July 2014; specimen \#6, NHMUK-EE 15409, top and bottom counterpart molds in concretion (Fig. 3.14-3.15), trench at foot of small hill about $5 \mathrm{~km}$ SSE of the village of Bantu, $23 \mathrm{~km} \mathrm{SW}$ of Alnif, SE Morocco $\left(30.92025^{\circ} \mathrm{N}, \quad 005.25339^{\circ} \mathrm{W}\right)$-Darriwilian; coll. S. Zamora, (September 2013). specimen \#7, NHMUK-EE 15413, top and bottom counterpart molds in concretion (Fig. 3.10, 3.11), trench at foot of small hill about $5 \mathrm{~km} \mathrm{SSE}$ of the village of Bantu, $23 \mathrm{~km} \mathrm{SW}$ of Alnif, SE Morocco $\left(30.92025^{\circ} \mathrm{N}, 005.25339^{\circ} \mathrm{W}\right)$-Darriwilian; coll. T. Ewin, A.B. Smith, and S. Zamora, (March 2012); specimen \#8, NHMUK-EE 16220, mold on surface of unopened concretion (Fig. 3.7), trench at foot of small hill about $5 \mathrm{~km} \mathrm{SSE}$ of the village of Bantu, $23 \mathrm{~km} \mathrm{SW}$ of Alnif, SE Morocco $\left(30.92025^{\circ} \mathrm{N}, 005.25339^{\circ} \mathrm{W}\right)$-Darriwilian; coll. S. Zamora (September 2014).

Additional specimens are in private collections or have been shown online ( 12 total that we know about): specimen in concretion posted on FossilForum website in 2010 by Moroccan collector and noted by Kyle Hartshorn (information sent to J. Sprinkle, June 2015); specimen in concretion purchased at Tucson Fossil Show, February 2013, by private collector after being photographed by Jeremy Savill (information and photo sent to J. Sprinkle, April 2014); two nearly complete and three partial specimens personally owned by Jeremy Savill and purchased between 2010 and 2015 (photos sent to J. Sprinkle, June 2015); partial specimen in concretion shown at the Munich Mineral Show by Moroccan collector (M. Reich, October
2015); two nearly complete and two partial specimens personally owned by Kraig Derstler and purchased between 2012 and 2015 (information given to J. Sprinkle, April 2016).

More than six years ago, an early Moroccan cyclocystoid was found (and shown to MR) deposited in a French private collection (Laurent Lacombe, later transferred to the collection of Patrick Catto); it represents the largest cyclocystoid specimen ever found (UCBL-FSL 712001). This early specimen remained in a private collection for several years until it was made available for scientific investigation and then acquired by the University of Lyon (UCBL-FSL). In the meantime, additional specimens were excavated by a London expedition team (Tim Ewin, Andrew B. Smith, Samuel Zamora; NHMUK) or offered for sale by commercial Moroccan fossil dealers (e.g., NPL).

All specimens are preserved as external molds either on slabs of fine-grained siliciclastic matrix (holotype) or in siderite-encrusted siliciclastic concretions (paratypes and other material). The cyclocystoids described here come from the Middle Ordovician Taddrist Formation of the First Bani Group (Darriwilian); the previously mentioned first specimen found (UCBL-FSL 712001) was erroneously reported as Upper Ordovician (Sandbian) in age (Lefebvre et al., 2008, 2010, 2013).

Photography, casting, and X-ray computed tomography.Specimens were digitally photographed both dry and whitened with ammonium chloride (Fig. 3.1-3.15). One specimen (holotype) was considered robust enough by its collector for latex and silicon casting of matched-counterpart molds, the standard technique, but this degraded the detail shown by the central disk and the radial ducts through the marginal ossicles.

Other concretionary cyclocystoid molds appeared to be too fragile for this type of casting. Therefore, the best-preserved specimens were investigated and additionally documented by high-resolution X-ray computed tomography at the University of Texas High-Resolution X-ray Computed Tomography Facility (UTCT) or at the Bavarian Natural History Collections (SNSB) in Munich (Figs. 4.1-4.10, 5.1, 5.2).

Scanning at these facilities attempted to differentiate the internal air-filled mold of the cyclocystoid from the enclosing siliciclastic matrix in its reassembled concretion encrusted by siderite. This nondestructive technique has recently been used to scan molds of arthropods and a few echinoderms in a variety of sedimentary rocks and concretions (e.g., Garwood et al., 2009; Legg et al., 2012; Rahman et al., 2012). Specimen 3 was scanned in March 2014 at UTCT with a Zeiss (formerly Xradia, Pleasanton, CA) MicroXCT 400 at $110 \mathrm{kV}$ and $0.09 \mathrm{~mA}$ using a $1.0 \mathrm{~mm} \mathrm{CaF}_{2}$ filter for a total of 881 slices at $49.0 \mu \mathrm{m}$ voxel size; specimens 4 and 5 were scanned in April 2016 at UTCT with an NSI scanner (North Star Imaging, Inc., Rogers, MN) at $150 \mathrm{kV}$ and $0.1 \mathrm{~mA}$ with no filter for a total of 977 and 986 slices with 62.6 and $95.6 \mu \mathrm{m}$ voxel size, respectively. Specimens 1 and 2 were scanned at the Bavarian Natural History Collections

\footnotetext{
Figure 3. General morphology and preservation of Moroccodiscus smithi n. gen. n. sp. from the Darriwilian (Middle Ordovician) of Morocco. (1, 2) Holotype UCBL-FSL 712001, top and bottom counterpart molds. (3, 4) Paratype UCBL-FSL 712000, top and bottom counterpart molds. (5, 6) Paratype NPL 74385, top and bottom counterpart molds. (7) Paratype NHMUK-EE 16220, exposed top mold on nearly unbroken concretion. (8, 9) Paratype NPL 62451, top and bottom counterpart molds. $(10,11)$ Paratype NHMUK-EE 15413, top and bottom counterpart molds. (12, 13) Paratype NPL 74386, top and bottom counterpart molds. $(\mathbf{1 4}, \mathbf{1 5})$ Paratype NHMUK-EE 15409, top and bottom counterpart molds. All images are photographs of moldic specimens whitened with ammonium chloride sublimate. Scale bar $=10 \mathrm{~mm}$.
} 


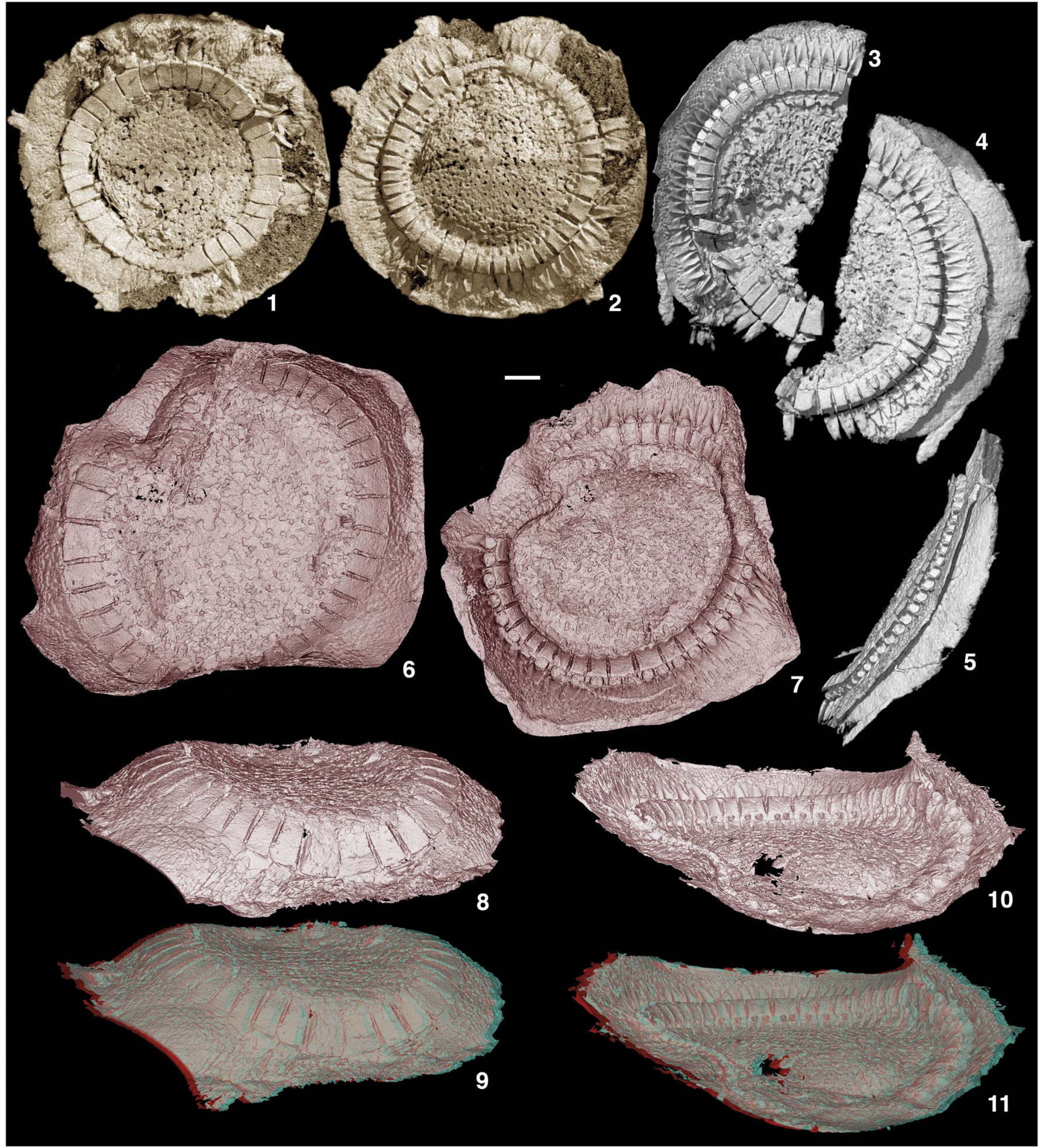

Figure 4. Digitally reconstructed general morphology of Moroccodiscus smithi $\mathrm{n}$. gen. n. sp. from the Darriwilian (Middle Ordovician) of Morocco, showing the central disk with pores, the ring of marginal ossicles, the ring of frontal plates, and a wide peripheral skirt. (1, 2) Paratype NPL 62451, bottom/top views. (3-5) Paratype NPL 74385: $(\mathbf{3}, \mathbf{4})$ top/bottom views; $(\mathbf{5})$ side view looking toward right edge of 4. (6-11) Paratype UCBL-FSL 712000: (6, 7) bottom/top views; $(8,9)$ side view looking toward right edge of $6 ;(10,11)$ oblique side view looking toward upper edge of $7 ;(9,11) 3 \mathrm{D}$ anaglyph images. Scale bar $=5 \mathrm{~mm}$.

(SNSB) Facility with a phoenix|x-ray nanotom $\mathrm{m}$ (GE Sensing \& Inspection Technologies $\mathrm{GmbH}$, Wunstorf/Hannover, Germany) at $150 \mathrm{kV}$ and $40 \mu \mathrm{A}(1,400$ slices with $42.9 \mu \mathrm{m}$ voxel size, respectively, and $0.25 \mathrm{~mm}$ copper filter), $90 \mathrm{kV}$ and $240 \mu \mathrm{A}(1,720$ slices with $23.5 \mu \mathrm{m}$ voxel size, respectively, and
$0.25 \mathrm{~mm}$ copper filter) as well as $170 \mathrm{kV}$ and $30 \mu \mathrm{A}(1,400$ slices with $27.9 \mu \mathrm{m}$ voxel size, respectively, and $0.25 \mathrm{~mm}$ copper filter).

Visualization and reconstruction were realized with different software applications including ImageJ, SPIERS, 


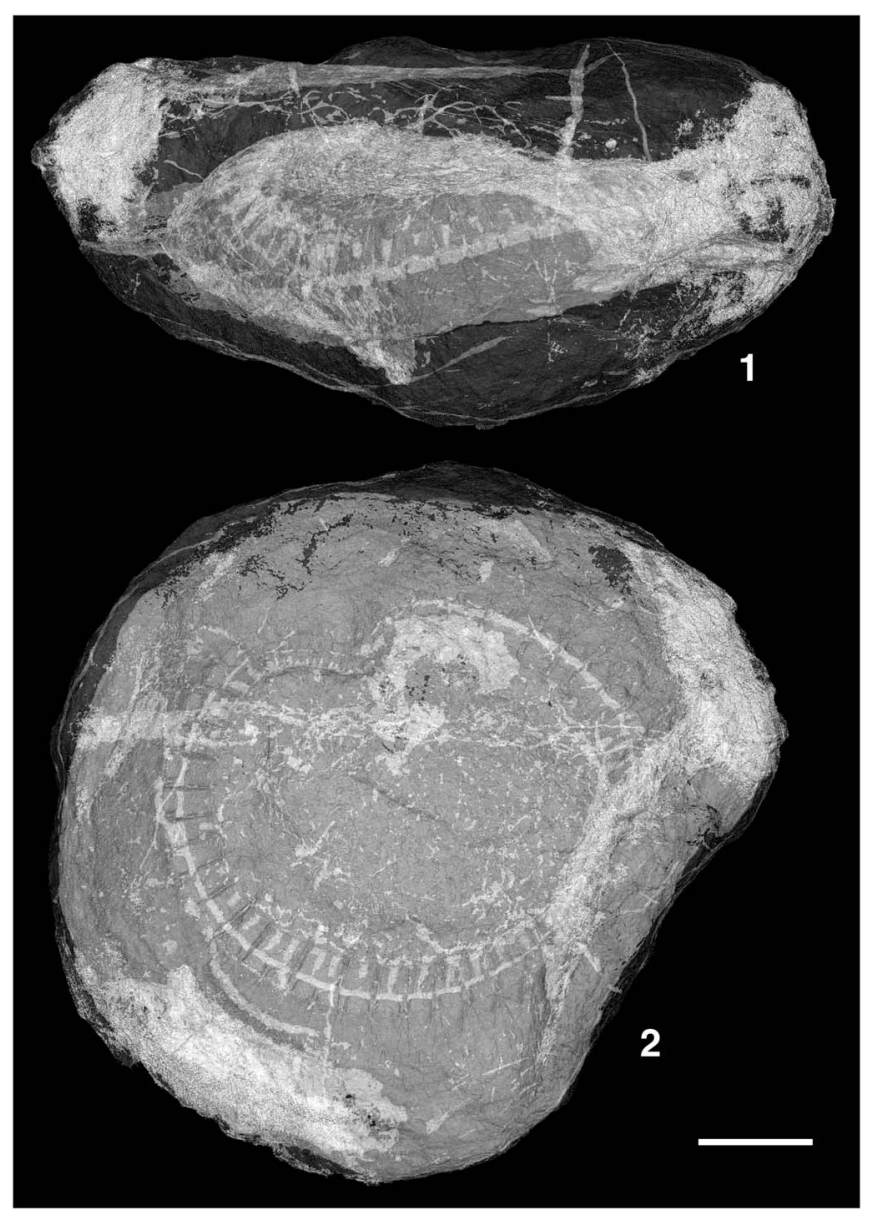

Figure 5. Semitransparent $\mathrm{CT}$ digital visualization of a concretion with Moroccodiscus smithi n. gen. n. sp. from the Darriwilian (Middle Ordovician) of Morocco. $(\mathbf{1}, 2)$ Paratype UCBL-FSL 712000 , lateral and bottom views. Scale bar $=10 \mathrm{~mm}$.

Avizo Lite v. 9.1, and VGStudio Max 2.2, 3.0 (cf. Rahman et al., 2012; Sutton et al., 2014). Drawings and figures were produced using Adobe Photoshop.

Web-deliverable versions of the animations for NPL paratypes 62451,74385 , and 74386 , as well as the original high-resolution X-ray CT data, are available at DigiMorph.org (http://digimorph.org/specimens/Moroccodiscus_smithi/NPL6 2451/, http://digimorph.org/specimens/Moroccodiscus_smithi/ NPL74385/, http://digimorph.org/specimens/Moroccodiscus_ smithi/NPL74386/).

\section{Systematic paleontology}

The terminology and classification used follows in part Smith and Paul (1982).

Subphylum Echinozoa (Haeckel in) von Zittel, 1895 Class Cyclocystoidea Miller and Gurley, 1895

Remarks.-At present there is still no accepted higher-level ('ordinary') classification of Cyclocystoidea. As a well-defined group of echinoderms, cyclocystoids consisted of a single (cupule-bearing) family - the Cyclocystoididae Miller, 1882 - for many years (Smith and Paul, 1982). However, Boczarowski (2001) revised the group by restricting the family Cyclocystoididae to include forms having a ring of 28-45 marginal ossicles and typically two cupules, as well as by proposing the Apycnodiscidae, including cyclocystoids with (16)18-33 marginal ossicles and 1-7 cupules each. We disagree with this systematic assumption (in simple counting of marginal ossicles) and accept (following in part Smith and Paul, 1982) that the absence or presence of cupules (with or without tubercles) and the arrangement of differently perforated marginal ossicles are more useful 'family' characteristics.

Family Moroccodiscidae Reich, Sprinkle, Lefebvre, and Zamora, new family

Type and only genus.-Moroccodiscus Reich, Sprinkle, Lefebvre, and Zamora, new genus.

Diagnosis.-Medium to large cyclocystoids lacking cupules attached to the marginal ossicles, and instead having hinged, elongate-trapezoidal frontal plates taking their place, one per radial duct.

Age and occurrence.-Middle Ordovician of Morocco, North Africa.

Discussion.-This Moroccan cyclocystoid appears to represent a new family because it lacks cupules on the outer edge of the marginal ossicles and has elongate-trapezoidal, trough-shaped frontal plates sutured there instead, one per radial duct through the ossicles.

Genus Moroccodiscus Reich, Sprinkle, Lefebvre, and Zamora, new genus

Type and only species.—Moroccodiscus smithi Reich, Sprinkle, Lefebvre, and Zamora, new species.

Diagnosis.-Medium to large, nearly circular (to subpentagonal) cyclocystoids with poorly defined radiating food grooves on two-layer central disk; marginal ossicles rectangular or trapezoidal, domed, having only one or two radial ducts, typically in a '22111121111' ray pattern in large specimens or '2211111111(1)' ray pattern in smaller specimens, no cupules on outside edge; frontal plates elongate, trough-shaped, one per marginal duct; peripheral skirt wide, beneath, between, and outside frontal plates.

Etymology.-Named for Morocco, where these specimens were found, and combined with the Latin discus $=$ disk.

Age and occurrence.-Middle Ordovician of southeastern Morocco, North Africa.

Discussion.—Moroccodiscus is clearly distinguished from all other cyclocystoid genera by lacking cupules on the outside edge of the marginal ossicles and by the presence of hinged, elongate-trapezoidal frontal plates instead. All other genera have cupules either with tubercles (Apycnodiscus 

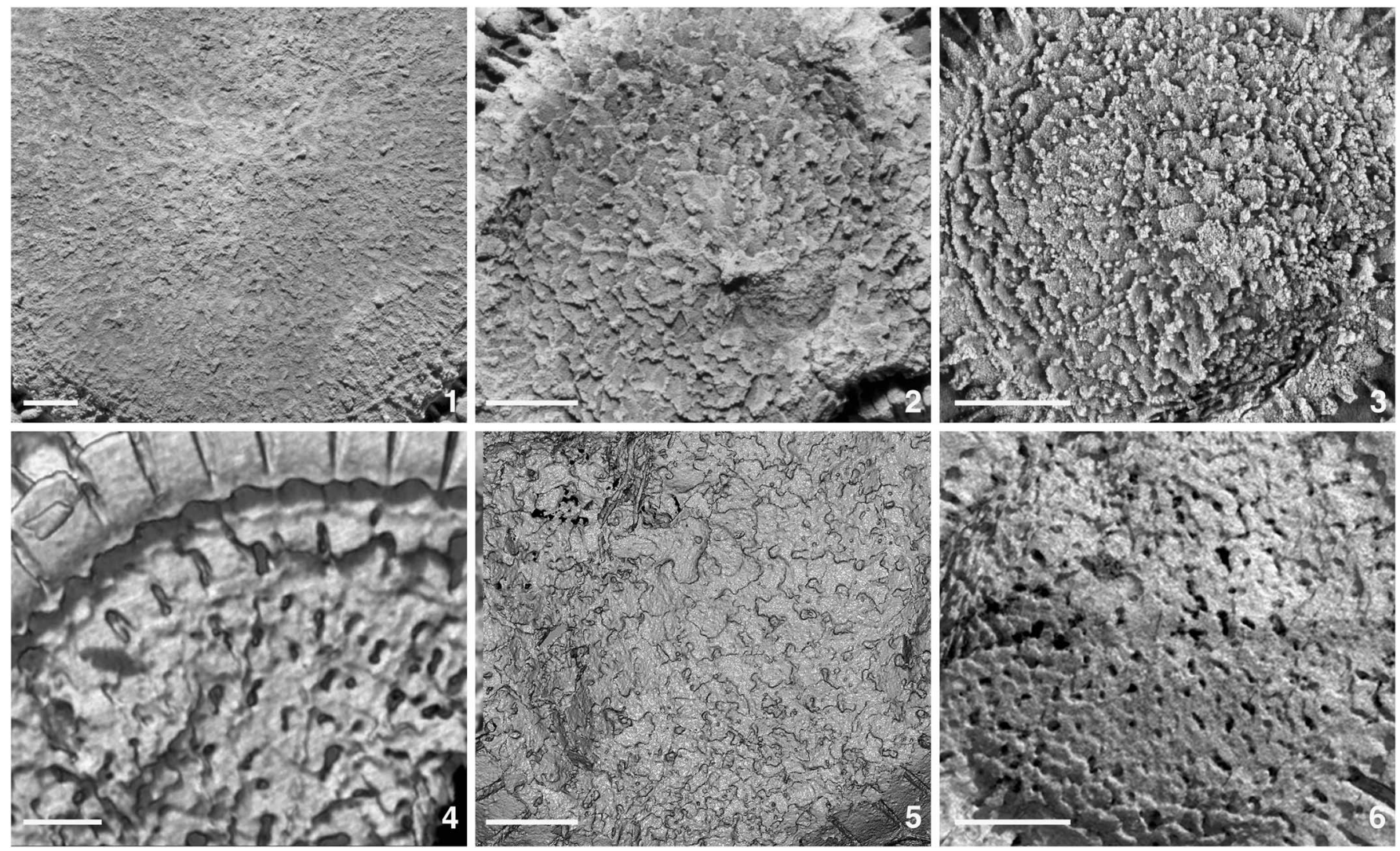

Figure 6. Detailed morphology and preservation of Moroccodiscus smithi n. gen. n. sp. showing the central disk (top side) made of small imbricating plates with pores between indistinct ambulacral grooves. (1) Holotype UCBL-FSL 712001. (2, 5) Paratype UCBL-FSL 712000. (3, 6) Paratype NPL 62451. (4) Paratype NPL 74385. (1-3) Photographs of moldic specimens whitened with ammonium chloride sublimate. (4-6) Digitally reconstructed CT images. Scale bars $=5 \mathrm{~mm}$.

Smith and Paul, 1982; Brutocycloides Boczarowski, 2001; Diastocycloides Smith and Paul, 1982; Polytryphocycloides Smith and Paul, 1982; Scotiadiscus Reich and Smith, 2008; Sievertsia Smith and Paul, 1982; Zygocycloides Smith and Paul, 1982), or without tubercles (Concavocycloides Boczarowski, 2001; Cyclocystoides Salter and Billings, 1858; Minicycloides Haude and Thomas, 1994; Monocycloides Berg-Madsen, 1987; Smithocycloides Boczarowski, 2001).

Two genera (Narrawayella Foerste, 1920; Nicholsodiscus Glass, Ausich, and Copper, 2003) are only known from specimens showing the non-cupule-bearing side, and a few others (Apparatocycloides Boczarowski, 2001; Chimaerocycloides Boczarowski, 2001; Linguacycloides Boczarowski, 2001; Neocyclocystoides Boczarowski, 2001; Paradoxocycloides Boczarowski, 2001; Platycycloides Boczarowski, 2001) are too poorly diagnosed because these are based only on isolated marginals from acetic/organic acid residues with limited diagnostic value because of preservation.

Moroccodiscus smithi Reich, Sprinkle, Lefebvre, and Zamora, new species

Figures 3-10

2015 New cyclocystoid specimen; Sprinkle et al., figs. 1A-F, 2D.
Holotype.-UCBL-FSL 712001, part and counterpart (casts NHMUK-EE 16221, SNSB-BSPG 2016 I 21, and NPL 83399).

Paratypes.-UCBL-FSL 712000, part and counterpart; NPL 62451, part and counterpart; NPL 74385, part and counterpart; NPL 74386, part and counterpart; NHMUK-EE 15409, part and counterpart; NHMUK-EE 15413, part and counterpart; NHMUK-EE 16220, unopened concretion.

Diagnosis.-Medium-large, nearly circular Moroccodiscus with two-layered, thin, central disk, slightly imbricate floor, and cover plates indistinct; 38-54 large, thick, rectangular, domed marginal ossicles with either one or two large radial ducts passing through them, no cupules on distal edge of marginal ossicles that overhangs duct entrance(s); frontal plates elongatetrapezoidal, thinner, trough-shaped, sutured to each marginal ossicle beneath each radial duct; peripheral skirt wide, imbricate, plate size decreasing outward, extending beneath, between, and outside frontal plates.

Age and occurrence.-The type section for M. smithi is a long trilobite trench with concretions in sandy and micaceous shale just above second sandstone interval near middle of Taddrist Formation (Darriwilian Stage, Middle Ordovician), ridge above Oued Tinzmite dry washes about $5.8 \mathrm{~km} \mathrm{SE}$ of small settlement of Battou on route N12, 23 km SW of town of 

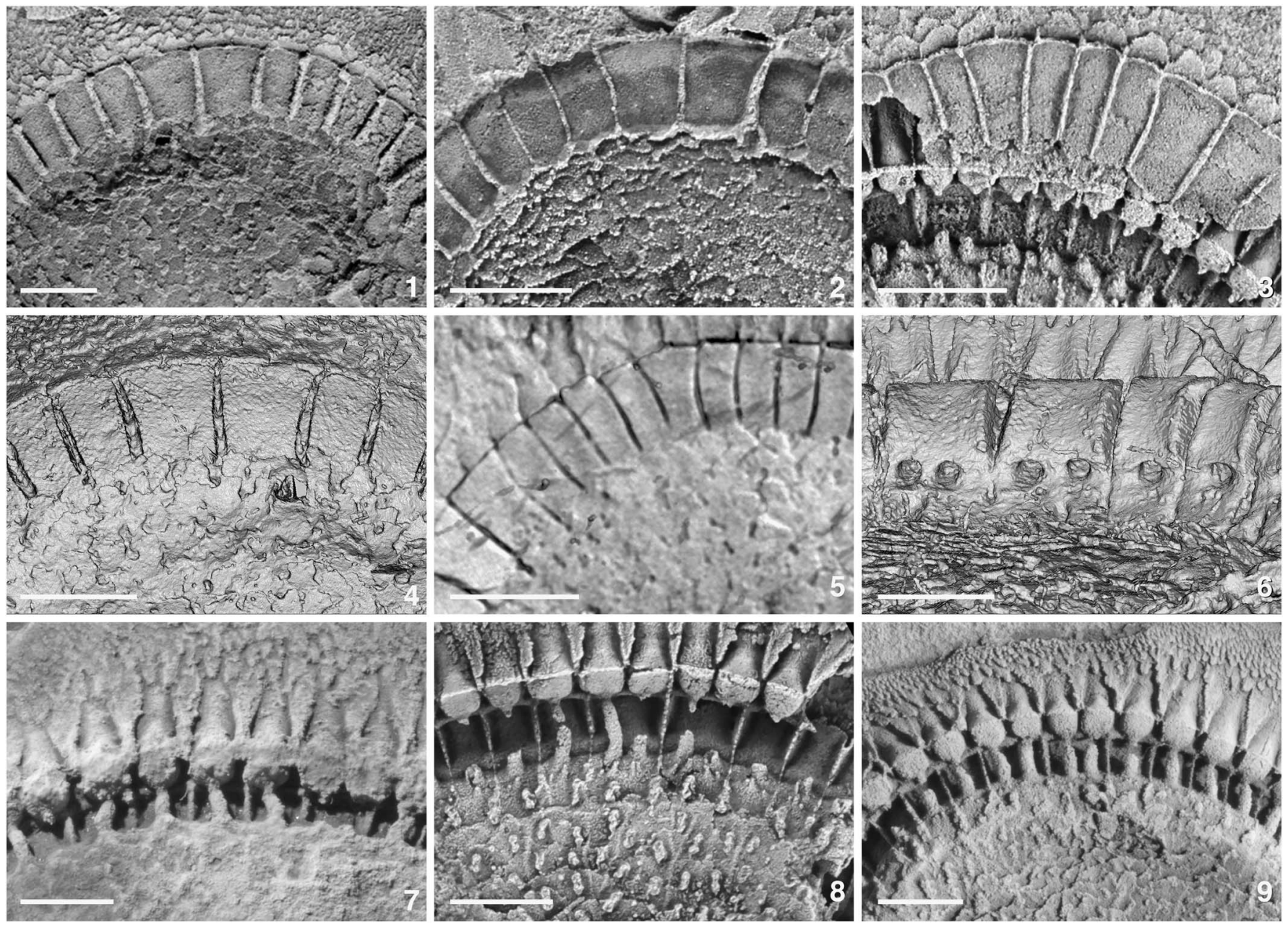

Figure 7. Detailed morphology and preservation of Moroccodiscus smithi n. gen. n. sp. showing the marginal ossicles and radial ducts. (1-5) rectangular- to trapezoidal-shaped marginal ossicles with one or two radial ducts; the latter ossicles are normally wider and/or trapezoidal. (1) Paratype UCBL-FSL 712000; (2) paratype NPL 62451; (3) paratype NPL 74385; (4) paratype UCBL-FSL 712000; (5) paratype NPL 74386. (6) Both types of marginal ossicles showing the radial duct openings; paratype UCBL-FSL 712000. (7-9) Partial marginal rings with steinkern fillings of radial ducts and molds of cupule-like cavities and frontal plates. (7) Holotype UCBL-FSL 712001; (8) paratype NPL 74386; (9) paratype UCBL-FSL 712000. (1-3, 7-9) Photographs of moldic specimens whitened with ammonium chloride sublimate. (4-6) Digitally reconstructed CT images. Scale bars $=5 \mathrm{~mm}$.

Alnif, eastern Anti-Atlas Mountains, southeastern Morocco, North Africa (see Rábano et al., 2014; Zamora et al., 2015). All known specimens of this cyclocystoid appear to have come from this same thin interval, although the locality has been given several different names by different collectors $\left(30.639525^{\circ} \mathrm{N}\right.$, $005.104275^{\circ} \mathrm{W} ; 30.92025^{\circ} \mathrm{N}, 005.25339^{\circ} \mathrm{W}$; and $30.55223^{\circ} \mathrm{N}$, $\left.005.15240^{\circ} \mathrm{W}\right)$.

Description.-Most specimens nearly circular, holotype very slightly subpentagonal, axially compressed, many specimens slightly convex on one side, nearly flat or slightly concave on the other side. Most of relief in studied molds located in ring of thick marginal ossicles. Central disk, frontal plates, and peripheral skirt very thin, easily damaged, and more difficult to interpret.

Central disk (Fig. 6): thin, domed, nearly circular area about $61 \mathrm{~mm}$ wide in holotype (about $68 \%$ of thecal diameter), about $20 \mathrm{~mm}$ wide in smaller paratype NPL 62451A (about $50 \%$ of diameter); composed of two tightly appressed, thin layers, upper layer of slightly imbricate (toward center), small (flooring?) plates, each bearing a central, shallow, radiating food groove with elongate pores laterally between plates; lower layer has more rounded pores within polygonal annular plates: two arc-shaped areas near outer margin of disk more disrupted, tilted up, and more clearly imbricate in scans (Fig. 6.1-6.6). Food grooves shallow, difficult to see, in some places marked by plated 'rays' between radiating lines of pores, cover plates on food grooves very small and cryptic, not usually seen; mouth small, usually near center of disk; folded paratype NPL 74386 (Fig. 3.12, 3.13) has small mouth opening partly exposed in fused area (oral frame?) with converging food grooves about one-third its diameter; periproct not seen, possibly lateral.

Marginal ossicles (Figs. 7, 8.1): Holotype having complete circlet of 54 large, rectangular to trapezoidal, thick ossicles with total of 68 radial ducts (Figs. 3.1, 3.2, 7.7, 8.1); smallest paratype NPL 62451 having nearly complete circlet of 33 large ossicles interrupted by about 9 stunted ossicles (Figs. 3.8, 3.9, $4.1,4.2,9.7)$ with total of about $54-55$ radial ducts; ossicles with one radial duct nearly rectangular, longer than wide (3.8$3.9 \mathrm{~mm}$ long, $2.2 \mathrm{~mm}$ wide), nine of these ossicles slightly wider 

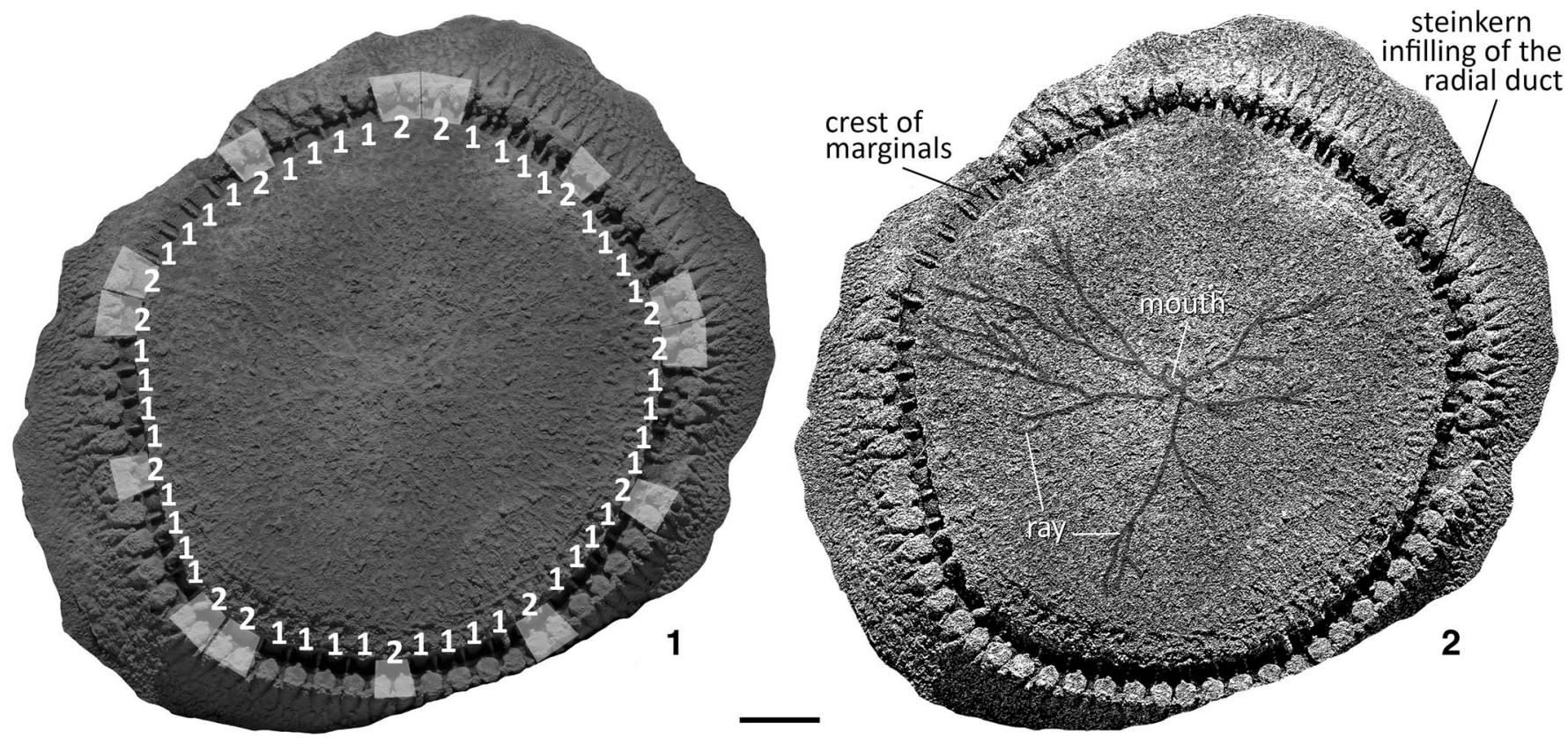

Figure 8. Large holotype (UCBL-FSL 712001) of Moroccodiscus smithi n. gen. n. sp. (1) Showing marginal ossicle arrangement; position of all double-pore ossicles marked. Note that paired double-pore ossicles all at subpentagonal corners. (2) Simplified diagram of the disk, showing the partly preserved pattern of ray branching. Scale bar $=10 \mathrm{~mm}$.

( $\sim 3.0 \mathrm{~mm}$ wide), with two radial ducts through center, six in pairs, wide, trapezoidal, three unpaired, slightly narrower, trapezoidal; 24 ossicles narrower $(\sim 1.8 \mathrm{~mm}$ wide, in 5-6 groups of 3-4) with only one radial duct; typical ossicle arrangement in each ray of large holotype and most other specimens is '22111121111' (e.g., Figs. 3.1, 3.2, 8.1), in smaller paratypes '2211111111(1)' (e.g., Figs. 3.3, 3.4, 3.8, 3.9, 4.2, 4.7, 7.9); marginal ossicles gently rounded on top, slightly tilted toward central disk with prominent overhang above duct entrances on distal edge (Fig. 9.1-9.4), separated by thin V-shaped gaps on rounded tops increasing in width distally (e.g., Fig. 7.5, 7.6); ossicles nearly flat on bottom surface with almost no gaps between them; ossicles having medium pustules on top, very small pustules (or stereom) on bottom; few marginal ossicles having slightly curved lateral sutures; one newly inserted ossicle present on paratype NPL 74385 (Fig. 4.4), wedge-shaped top edge does not reach distal edge of ring with gap partly filled by curved edges of adjacent ossicles. No obvious cupules with or without tubercules on distal side of marginal ossicles, which have slightly rounded lower edges sutured to frontals.

Frontal plates (Fig. 9.1-9.5): separate, elongate-trapezoidal, distally tapering, trough-shaped frontal plates attached to lower distal edge of a marginal ossicle (e.g., Fig. 9.1, 9.2, 9.4), each one leading to duct through a marginal (Figs. 7.6, 9.5); about 47 nearly complete frontals present (visible) in holotype UCBL-FSL 712001, 27 present in paratype UCBL-FSL 712000, and 33-34 complete frontals present in paratype NPL 62451; others covered, missing, or in stunted segments; frontals slightly shorter and much thinner than adjacent marginal ossicles, about $3.5 \mathrm{~mm}$ long and $1.5 \mathrm{~mm}$ wide; laterally bounded (and underlain) by inner edge of imbricate peripheral skirt.

Peripheral skirt (Fig. 9.6-9.8): edge of specimens gradually tapering in thickness, plated below with about 15 diagonal rows of small to tiny, imbricate, arc-shaped to triangular plates decreasing in size outward, extending between (in V-shaped notches), below, and beyond frontal plates (e.g., Fig. 3.1, 3.4-3.6, 3.8, 3.9). Skirt easily damaged; in small paratype NPL 62451 , about one-third of wide skirt missing near where several disrupted frontals present (e.g., Figs. 3.8, 3.9, 4.1, 4.2); plating widest on bottom where skirt about $6-7 \mathrm{~mm}$ wide in small paratypes, up to $9.5 \mathrm{~mm}$ wide in much larger holotype.

Other features: several plate types (central disk plates, marginal ossicles, frontal plates) show a frosted surface (possibly stereom or tiny pustular ornament) in smoked mold photos or CT scans. The apparent top of the mold is concave and the apparent bottom of the mold is slightly convex as preserved in the original concretion, implying that the original cyclocystoid plating is convex on the top(?) surface and slightly concave on the bottom(?) surface. The central disk with its convex curvature often matches wispy, curved, white lines seen in several concretions (Fig. 10.1, 10.3).

Etymology.- - Named for Andrew B. Smith, recently retired from the Natural History Museum, London, who revised the known cyclocystoids for a major monograph in the late 1970s to early 1980s and named many new genera and species (Smith and Paul, 1982; Smith and Wilson, 1995; Reich and Smith, 2008).

Discussion.-The shape and morphology of marginals and frontal plates distinguish this new genus and species from all other known cyclocystoid genera. During ontogeny, the marginal ossicle arrangement apparently changed from 2211111111 (1) (e.g., Figs. 3.3, 3.4, 3.8, 3.9, 4.2, 4.7, 7.9) to 22111121111 (Figs. 3.1, 3.2, 8.1). The detailed arrangement of perforated marginals is clearly understudied in previously described 

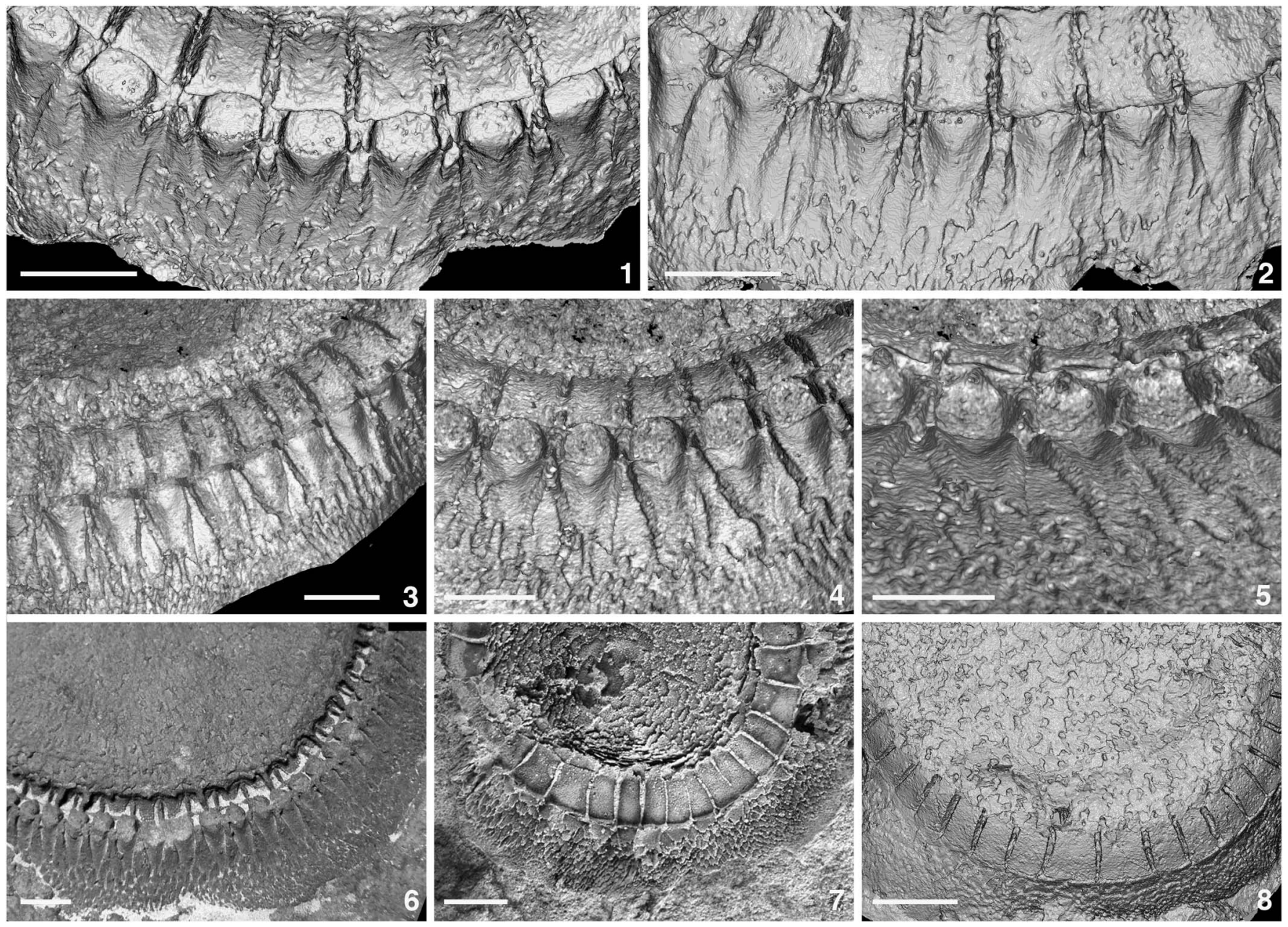

Figure 9. Detailed morphology and preservation of Moroccodiscus smithi $\mathrm{n}$. gen. n. sp. showing the frontal plates and the peripheral skirt. (1-5) Digitally reconstructed CT images showing the elongate-trapezoidal trough-shaped frontal plates in different views; paratype UCBL-FSL 712000. (6-8) Small to tiny, imbricate plates (up to 15 rows) of the wide peripheral skirt in different views: (6) moldic holotype UCBL-FSL 712001 top view, not whitened; (7) moldic paratype NPL 62451 bottom view, whitened with ammonium chloride sublimate; (8) paratype UCBL-FSL 712000 bottom view, digitally reconstructed CT image. Scale bars $=5 \mathrm{~mm}$.

cyclocystoid species but will help in future discussions on higher-level systematics within the Cyclocystoidea.

The elongate, concave frontals sutured to the sloping back edges of the marginal ossicles, mostly under the distal overhang of these large domed plates, the ducts through these plates leading to radiating and distally branching food grooves on the domed central disk, and eventually leading to a central body opening (the mouth?), resembles the upward-facing foodgathering systems of other suspension-feeding echinoderms, such as edrioasteroids. Extending the distal edge of the marginal ossicles into an exposed concave structure and shortening the frontals and perhaps changing their function would produce the cupules found in most other Ordovician cyclocystoids. Some authors, such as Nichols (1969), considered that cupules housed large tube feet, whereas Smith and Paul (1982) believed that these distinct and obviously important skeletal structures were not associated with tube feet. From the partially visible pattern of ray branching in the holotype (UCBL-FSL 712001) and the possible mouth opening near the center of the folded central disk in paratype NPL 74386 of Moroccodiscus, we can assume that the mouth is also located near the center of the disk in all specimens of this new species. The interior of the domed central disk has no basal plated surface extending in from the marginal ossicle ring in CT scan cross sections (Fig. 10.1, 10.2). We believe that cyclocystoids were sessile suspension feeders living directly on the seafloor, with the central disk upward and the soft parts protected below it (Sprinkle et al., 2015).

\section{Radial versus interradial orientation in cyclocystoids}

Cyclocystoids are nearly radially symmetrical with relatively little irregularity. The mouth appears to have been located in the center of the oral disk in the few specimens where it has been identified, and all the ambulacral grooves, if preserved, apparently lead to this point (Smith and Paul, 1982). The periproct has not been identified in cyclocystoids but, if present, was probably lateral in the posterior interray of the oral disk. The peripheral ossicles, however, do show some irregularity in Moroccodiscus and other genera. Because the ambulacra branch dichotomously (Fig. 8.2) during growth away from the central mouth, the marginal ossicles with their pores, cupules, and/or frontal plates 


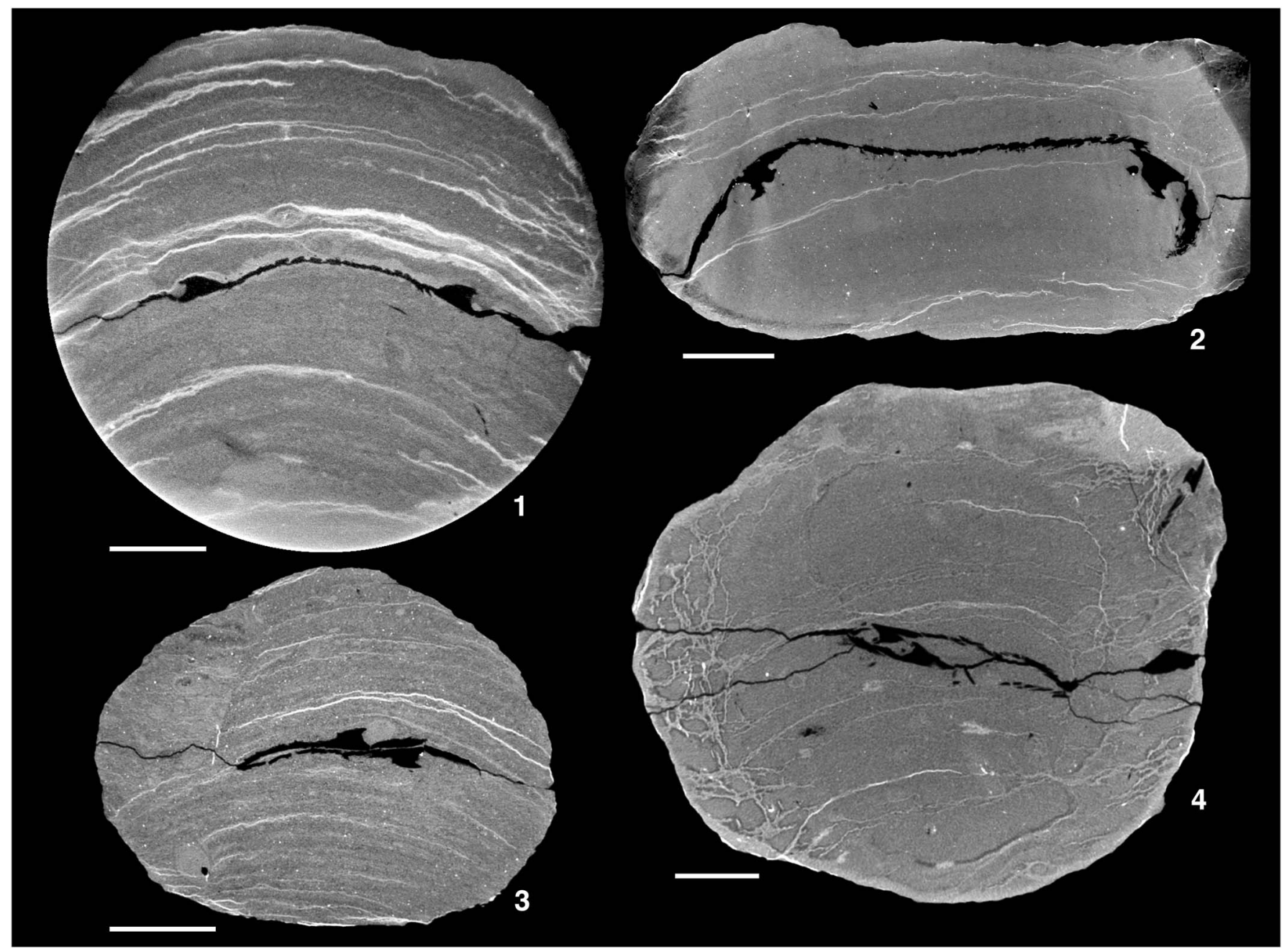

Figure 10. Different slices of X-ray CT-scanned specimens of Moroccodiscus smithi n. gen. n. sp., showing various burial features including partial disarticulation, wispy, curved, light-colored, sediment layers in the concretions, and a few light gray burrows. (1) Well-articulated complete specimen (paratype NPL 62451; slice 360) showing undisturbed burial with domed central disk, nearly flat marginal ossicles, and slightly raised frontal plates and peripheral fringe, all nearly matching curved, wispy, sediment layers; break into concretion at right. (2) Nearly articulated specimen (paratype UCBL-FSL 712000; slice 845) showing undisturbed burial with a nearly flat central disk but highly depressed marginal ossicles, frontal plates, and peripheral fringe (here upside down?) along curved edges of diagenetically growing concretion. (3) Folded specimen (paratype NPL 74385; slice 527) in smaller concretion with little siderite showing wellpreserved central disk on left and raised tops of marginal ossicles facing outward on right. (4) Folded specimen (paratype NPL 74386; slice 590) in large concretion with many cracks and siderite-encrusted areas showing slightly disarticulated central disk on right and raised tops of marginal ossicles facing inward on left. $(3,4)$ Show evidence of more severe seafloor disturbance before burial. Scale bars $=10 \mathrm{~mm}$.

have to increase in number to match the number of ambulacral grooves. Moroccodiscus has marginal ossicles arranged in a fairly consistent pattern with one pore through them (most common, 40 total), two pores through a single isolated ossicle (mostly in the larger specimens, usually five total), or two pores through two adjacent ossicles (second most common, usually 10 total) (cf. Figs. 7.1, 7.2, 7.4, 7.6, 8.1). We think the paired double-pore ossicles are most likely interradial and maintain this position, the single-pore ossicles are radial across an ambulacral dichotomous array, and the single double-pore ossicles are added late in ontogeny in the center of this array to support a few more ambulacral branches. In the very large holotype of Moroccodiscus, there are 54 marginal ossicles, one less than expected in a specimen with a full complement of adult ossicles; one double-pore ossicle may be missing from this specimen (Fig. 8.1, lower-right side). Up to 10 primary rays may enter the central mouth, even if only five of them are well enough preserved to be drawn (Fig. 8.2) in this partly weathered specimen. This is a much higher number than previously recorded from other genera (six in Cyclocystoides and Scotiadiscus, five in Sievertsia and Zygocycloides, and four in Apycnodiscus and Polytryphocycloides). By contrast, the relatively small paratype NPL 62451 has only four double-paired two-pore ossicles, perhaps indicating that it had only four ambulacral rays (Fig. 4.1, 4.2), but this may have been affected by the short segment of small stunted plates in the ossicle ring (Fig. 4.2, top).

\section{Growth in cyclocystoids}

Like most other fossil and living echinoderms, cyclocystoids can be inferred to have had a free-floating, microscopic larval stage, which was followed by settlement on a suitable substrate and metamorphosis into a tiny, few-plated juvenile version of 
the adult body plan. It then probably had a very small oral disk, only five or 10 small, wedge-shaped marginal ossicles, perhaps the same number of frontal plates, and a thin, peripheral fringe. During growth, it then grew the early-formed plates, added new ones between the existing marginal ossicles and frontal plates (we have one example of this [Fig. 4.4], much like a similar example in Smith and Paul, 1982, fig. 12), added new floor(?) plates in rough circlets distal to the existing ambulacral floor plates to lengthen and branch the ambulacra, and added tiny plates to expand the peripheral skirt. We have (or have seen) specimens of this new cyclocystoid ranging from about $30 \mathrm{~mm}$ in diameter (incomplete paratype NHMUK-EE 16220), probably a medium-sized juvenile, to around $85 \mathrm{~mm}$ in diameter (holotype UCBL-FSL 712001), probably a gerontic adult, with a range of 38 to 54 marginal ossicles, indicating that we are missing most of the juvenile stage. The number of ossicles seems more variable in Moroccodiscus, probably because of its large size, compared to other Ordovician genera with a fixed number of cupules and pores (one or two) per ossicle.

\section{Stunted segment in marginal ring}

Several specimens (e.g., UCBL-FSL 712000 and NPL 62451) have marginal ossicles (and surrounding plates) in a damaged area stunted and depressed(?) to about half normal size, with central disk plates protruding distally outward (or depressed inward) and peripheral skirt narrower and depressed slightly inward proximally and appreciably inward distally. The damaged area on paratype NPL 62451 is about $5.1 \mathrm{~mm}$ wide (about $6.5 \%$ of the marginal ossicle ring circumference) and contains several sets of polygonal plates on the flat bottom surface and 12-14 tiny radial ducts extending inward (Fig. 4.2). This implies that about nine or 10 marginal ossicles were affected, most with one pore but a few with two pores. The damaged area probably contained a missing two-pore ossicle on one edge and paired two-pore ossicles near the other edge to agree with adjacent ossicles.

The stunted segment is much larger on paratype UCBLFSL 712000a, producing a large indent into the usually circular central disk and a smaller indent into the distal peripheral fringe (Fig. 4.7). The stunted segment is at least $16.2 \mathrm{~mm}$ wide measured along a curved line (about $15 \%$ of the marginal ossicle ring circumference) and includes 17-18 stunted marginal ossicles and frontal plates. Damaged areas such as these with their stunted plates probably indicate previous injuries or nonfatal predation to the margin of the cyclocystoid causing the plates there to either stop growing or regenerate incompletely, but never catching up to normal growth of marginal plates in the adjacent undamaged areas. Similar regeneration features in Paleozoic crinoids, including nipped and regrown arms, regenerated anal tubes, and small plates filling in holes where large cup plates were damaged, have been illustrated by Gahn and Baumiller (2010).

\section{Folded-over specimens}

The two Derstler complete paratypes (NPL 74385 and NPL 74386) and one of Savill's partial specimens in his personal collection appear to have the cyclocystoid folded over through the central disk with arcs of the top and bottom surfaces partly or mostly superimposed on what appears to be a half specimen (Figs. 3.5, 3.6, 3.12, 3.13, 4.3-4.5). CT scans of both NPL concretions show most of the central disk membrane folded over with only slight disruption, implying a very flexible central disk, whereas the marginal disk ossicles near the edges of the specimen are snapped apart along sutures and doubled over. Perhaps most interesting is that the foldings in these two specimens have the opposite orientation; smaller paratype NPL 74385 has the domed tops(?) of the marginal ossicles facing outward (Fig. 10.3), whereas larger paratype NPL 74386 has the domed tops(?) of the marginal ossicles facing inward (Fig. 10.4). This probably occurred when living cyclocystoids were subjected to high currents or slumping sediments in storms and were flipped or folded over until the ossicle ring partly broke either before final burial or after burial during compaction of the accumulating sediment. This unusual preservation apparently has not previously been reported in other cyclocystoid genera, judging from figures in Smith and Paul (1982), nor in similarly shaped domal edrioasteroids. Perhaps this resulted from the large size of Moroccodiscus versus other cyclocystoids (which weakened and allowed folding of the flattened theca), later changes in cyclocystoid morphology that strengthened the marginal disk and prevented folding in high currents, or the deeper water and fine clastic sediment that rarely formed hardgrounds to which Moroccodiscus specimens could tightly adhere. Edrioasteroids are more commonly found attached to skeletonized fossils or to hardgrounds in carbonate settings, and are rarely found detached from their living position and deformed.

\section{Orientation in life and paleoecology}

Most earlier authors who named and studied cyclocystoids (Salter and Billings, 1858; Foerste, 1920; Sieverts-Doreck, 1951; Kesling, 1963, 1966; Kolata, 1975) reconstructed them as small-particle suspension feeders living with the flattened ventral side recumbent on or attached to the seafloor. Most later authors (starting with Nichols, 1969, but especially Smith and Paul, 1982, followed by Berg-Madsen, 1987; Rowe, 1988; Glass et al., 2003) reconstructed cyclocystoids as mobile, smallparticle deposit feeders with the convex surface down and no large body cavity. Our preliminary report on this new cyclocystoid (Sprinkle et al., 2015) mostly used the morphology of Smith and Paul (1982), but argued that the inferred orientation and life mode used by earlier authors was more likely to be correct.

If cyclocystoids lived convex central disk down (Smith and Paul, 1982), the body space within the cyclocystoid disk would be very small, leaving little room for the digestive system and other soft parts needing protection. For this reason, Smith and Paul (1982) assumed that cyclocystoids had a small, sac-like gut, and much of the digestion and adsorption may have occurred in the permanently covered radial channels. However, the round, flattened shape of this new cyclocystoid, the domed central disk, and the lack of an enclosed body cavity containing the soft parts of the animal indicate to us that cyclocystoids most likely lived with their flat marginal surface downward, sitting 
Middle Ordovician (Dapingian \& Darriwilian)

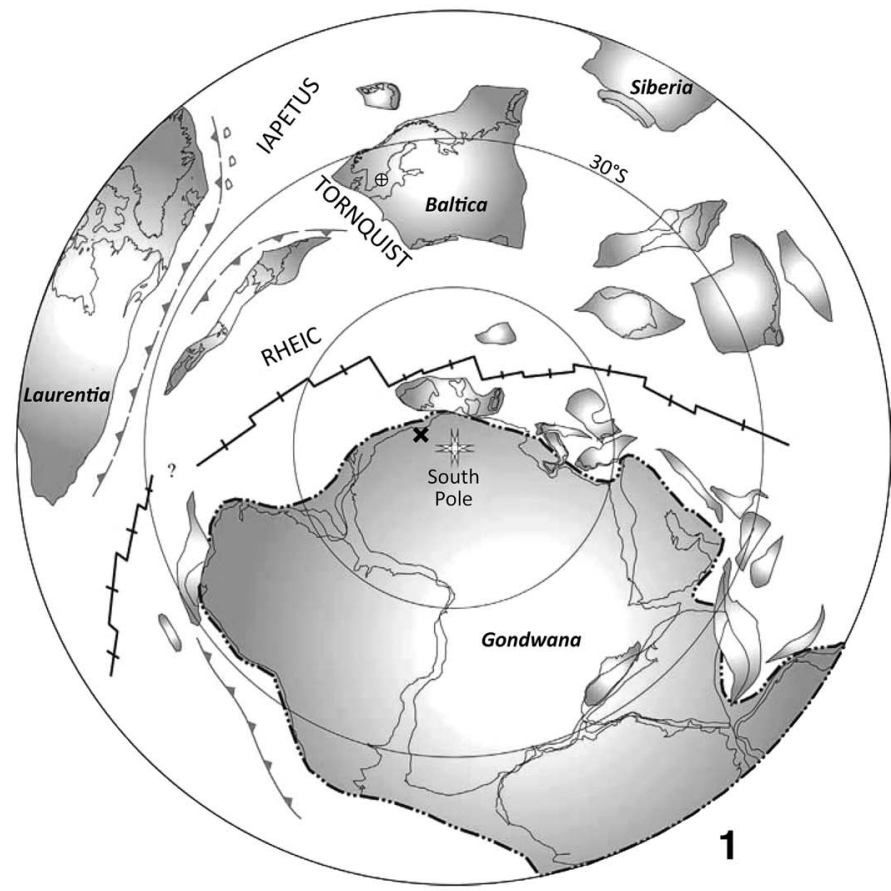

$\oplus$ Monocycloides

$\times$ Moroccodiscus
Late Ordovician

\section{(Sandbian, Katian \& Hirnantian)}

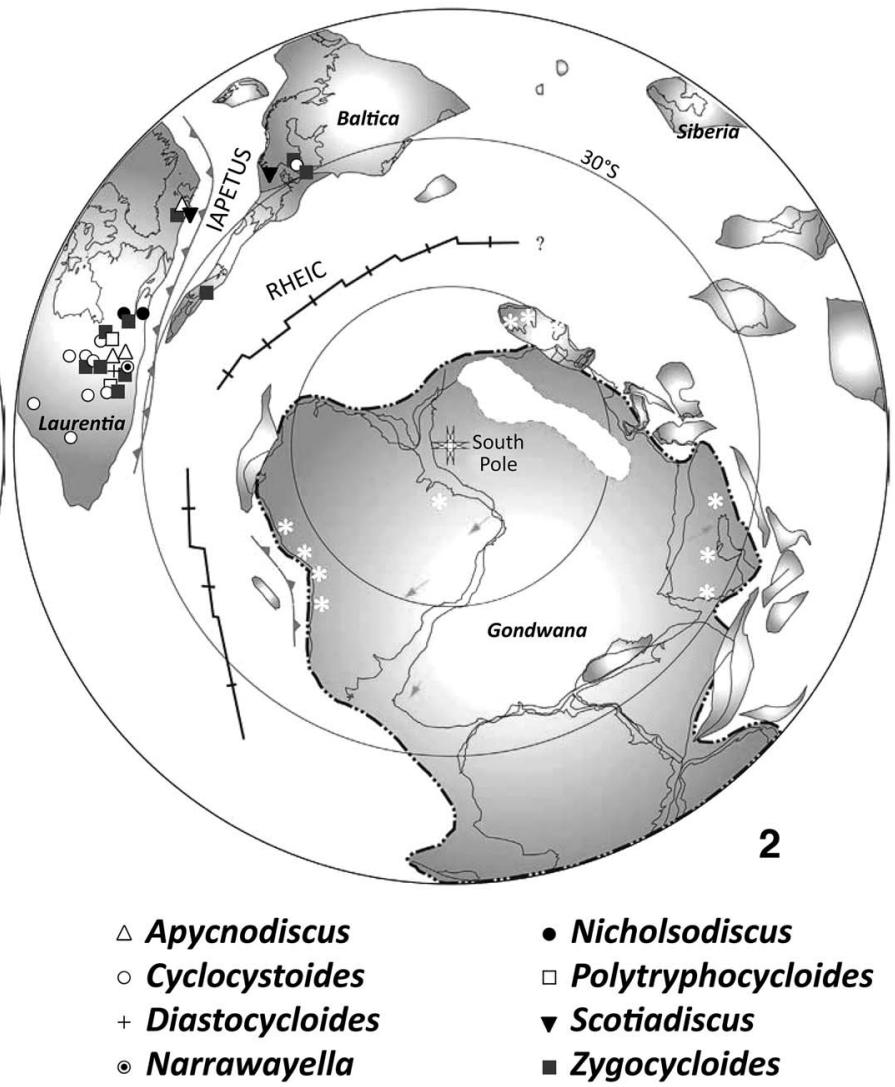

Figure 11. Distribution of the major paleocontinents during the (1) Middle and (2) Late Ordovician, showing the known geographical distribution of cyclocystoid genera: Apycnodiscus, Cyclocystoides, Diastocycloides, Monocycloides, Moroccodiscus, Narrawayella, Nicholsodiscus, Polytryphocycloides, Scotiadiscus, and Zygocycloides (paleogeography from Cocks and Torsvik, 2006; white stars in 2 indicating glacial dropstones, tillites etc.).

on or attached to the seafloor like most post-Cambrian domal edrioasteroids (Guensburg, 1988; Sumrall, 1994). The elongate frontal plates, convex marginal ossicles, and domed central disk with its radiating food grooves were upward-facing regions where food particles were first collected and then transported to a central mouth. The body cavity with these soft parts below the domed central disk sat directly on the seafloor without an underlying plated surface. The flat side of the marginal ring plates and especially the surrounding imbricate peripheral skirt held the cyclocystoid down on the seafloor using the weight of the thick marginal ossicles, perhaps aided by soft-part suction or actual cementation to a stabilized or lithified substrate. Our very large holotype specimen from Morocco is sitting on a yellowish-brown slab that may have been a hardground. Ordovician cyclocystoids are sometimes found on stained carbonate hardgrounds in tropical Laurentia, where cementation was common (e.g., Wilson et al., 1992), and they are predominately found flattened side down (Kolata, 1975; personal communication, T. Guensburg, 2015). However, cyclocystoids are almost never found attached to skeletonized organisms such as brachiopods, trilobites, or conularids, unlike edrioasteroids that commonly attached to these hard substrates (see Sumrall and Zamora, 2011).

\section{Paleogeography and relationship to other cyclocystoids}

Moroccodiscus is the oldest known articulated cyclocystoid and only sligthly younger than the oldest cyclocystoid plates (Monocycloides; Berg-Madsen, 1987) from the early Darriwilian of Sweden. In contrast to formerly published views (Smith and Paul, 1982), the paleogeographic origins of cyclocystoid echinoderms still remain uncertain and mysterious (Fig. 11) as the previously mentioned oldest (isolated) cyclocystoid material was described from Baltica (BergMadsen, 1987), the new form described herein comes from high-latitude Gondwana (Fig. 11.1), but most of the other Ordovician (articulated and disarticulated) cyclocystoids have been reported from Laurentia and Avalonia (Sandbian and Katian; e.g., Kolata, 1975, 1982; Smith and Paul, 1982; Glass et al., 2003; Fig. 11.2, Table 1). The other Ordovician fossil record of cyclocystoids from Baltica is rather poor (Männil, 1983; Reich et al., 2007; Lefebvre et al., 2013; Table 1) and based only on disarticulated material.

Moroccodiscus may be most closely related to Monocycloides from Baltica, which is very slightly older, and Cyclocystoides from Laurentia and Baltica, which is slightly to much younger, because both of these genera have cupules that 
lack tubercles on the marginal ossicles, unlike other Ordovician and most later cyclocystoid genera.

\section{Conclusions}

The new cyclocystoid Moroccodiscus smithi is described from the middle Taddrist Formation (Darriwilian, Middle Ordovician) in southeastern Morocco from eight type specimens. Most specimens are preserved as molds in split-apart siderite concretions and have been CT scanned (a nondestructive imaging technique) instead of being cast in latex or silicone, which would have damaged fragile structures. Moroccodiscus is assigned to the new family Moroccodiscidae because it lacks the cupules on the distal side of the marginal ossicles found in many other cyclocystoids. Food-gathering structures may have been shared between the distal edge of the marginal ossicles and the proximal edge of the elongate frontal plates. Moroccodiscus is the first Ordovician cyclocystoid found in Gondwana and is the earliest cyclocystoid known from complete articulated specimens.

Most of our Moroccodiscus specimens are either medium to large juveniles or large adult specimens. We do not have any small juveniles from early in ontogeny in our sample. Two of the Moroccodiscus specimens have stunted and perhaps damaged areas in their marginal ossicle rings, perhaps indicating an injury or nonlethal predation in early ontogeny. Two other specimens have been preserved folded over in opposite orientations in their concretions, indicating severe storm activity or large-scale slumping of the seafloor was the likely cause of death in these specimens. This type of preservation has not previously been reported in other cyclocystoid (or similarly shaped domal edrioasteroid) occurrences.

The morphology and preservation of Moroccodiscus indicate that cyclocystoids were most likely sessile, benthic suspension feeders with the domed side up and a life mode similar to domal edrioasteroids. However, this early cyclocystoid does not seem to be closely related to any known group of edrioasteroids. Cyclocystoids may have originated in Baltica or NW Gondwana in the Middle Ordovician (Darriwilian), but rapidly spread to several other plates (Laurentia and Avalonia) by the Late Ordovician (Sandbian and Katian), where they greatly increased in diversity and abundance.

\section{Acknowledgments}

CT scanning and digital photography were funded by NSF Grants EAR-1258878 (to UTCT) and DBI-0646468 (to A. Molineux and JS at the NPL). In addition, this study was supported by a Ramón y Cajal Grant (RYC2012-10576) and projects CGL2012-39471 and CGL2013-48877 from the Spanish Ministry of Economy and Competitiveness (to SZ), as well as in part by Synthesys grants, a program financed by European Community Research Infrastructure Action: CZTAF-3848 (Prague), GB-TAF-2446 (London), and SETAF-2969 (Stockholm) (to MR). Furthermore, this paper is a contribution of the RALI (Rise of Animal Life) project, which is funded by the ANR (Agence Nationale de la Recherche, France; grant number ANR-11-BS56-0025 (to BL). For facilitating access to material under their care, we are indebted to C. Franzén (NRM Stockholm), G. Heumann (University of Bonn), R. Prokop and M. Valent (both NM Prague), T.A.M. Ewin and A.B. Smith (both NHM London), E. Robert (UCBLFSL Lyon), and J. Waddington and D. Rudkin (both ROM Toronto).

We thank P. Catto (Bain-de-Bretagne) for donating the two UCBL-FSL specimens and providing information on their locality; K. Derstler (University of New Orleans) for donating two unusual specimens he had purchased to the NPL for this project; and Moussa Minerals \& Fossils and K. Martyn for their help in acquiring the first NPL cyclocystoid and determining its true collection locality. The authors also thank J. Maisano and M. Colbert (UTCT Austin) for their assistance in X-ray CT scanning and rendering; D. Sprinkle (Austin), A. Thompson (NPL Austin), and M. Schellenberger (SNSB-BSPG Munich) helped with photographs and drawings.

Our paper benefited greatly from detailed and insightful reviews by T. Guensburg (Rockford, Ill.) and C.R.C. Paul (Bristol, UK). Further discussions with several colleagues, including A.B. Smith (NHM London), R. Haude (University of Göttingen), and R. Prokop (NM Prague) are gratefully acknowledged.

\section{References}

Alessandrello, A., and Bracchi, G., 2003, Eldonia berbera n. sp., a new species of the enigmatic genus Eldonia Walcott, 1911 from the Rawtheyan (Upper Ordovician) of Anti-Atlas (Erfoud, Tafilalt, Morocco): Atti della Societa Italiana di Scienze Naturali e del Museo Civico di Storia Naturale de Milano, v. 144, no. 2, p. 337-358.

Allaire, N., Lefebvre, B., Martin, E., Nardin, E., and Vaucher, R., 2015, Taphonomy of new Rhopalocystis assemblages in the Lower Ordovician of the Zagora area (central Anti-Atlas, Morocco), in Zamora, S., and Rábano, I., eds., Progress in Echinoderm Palaeobiology: Cuadernos del Museo Geominero, v. 19, p. 21-26.

Barrande, J., 1872, Système Silurien du centre de la Bohême. 1ère partie: Recherches paléontologiques. Supplément au Vol. 1. Trilobites, crustacés divers et poissons: Prague, C. Bellmann, 647 p.

Begg, J.L., 1934, On the Genus Cyclocystoides: Geological Magazine, v. 71 , no. 5 , p. 220-224.

Begg, J.L., 1940, On the Genus Cyclocystoides, with a description of a new species from the Ashgillian of Girvan: Transactions of the Geological Society of Glasgow, v. 20, no. 1, p. 21-29. [preprint 1939].

Beisswenger, M., 1994, A calcichordate interpretation of the new mitrate Eumitrocystella savilli from the Ordovician of Morocco: Paläontologische Zeitschrift, v. 68, p. 443-462.

Berg-Madsen, V., 1987, A new cyclocystoid from the Lower Ordovician of Öland, Sweden: Palaeontology, v. 30, no. 1, p. 105-116.

Bergström, S.M., Chen, X., Gutiérrez-Marco, J.C., and Dronov, A.V., 2009, The new chronostratigraphic classification of the Ordovician System and its relations to major regional series and stages and $\delta^{13} \mathrm{C}$ chemostratigraphy: Lethaia, v. 42, no. 1, p. 97-107.

Billings, E., 1865 [1861-1865], Palæozoic Fossils. Volume I. Containing Descriptions and Figures of New or Little Known Species of Organic Remains from the Silurian Rocks: Montreal, Dawson Brothers, and London, New York, and Paris, Baillière, 426 p. [1861: p. 1-24; 1862: p. 25-168; 1865: p. 169-426]

Boczarowski, A., 2001, Isolated sclerites of Devonian non-pelmatozoan echinoderms: Palaeontologia Polonica, v. 59, p. 3-220.

Botting, J.P., 2007, 'Cambrian' demosponges in the Ordovician of Morocco: insights into the early evolutionary history of sponges: Geobios, v. 40 , no. 6 , p. $737-748$.

Chauvel, J., 1966, Echinodermes de l'Ordovicien du Maroc: Paris, Ed. CNRS, $120 \mathrm{p}$.

Chauvel, J., 1969, Les échinodermes macrocystellides de l'Anti-Atlas marocain: Bulletin de la Société Géologique et Minéralogique de Bretagne, v. 1, p. $21-32$. 
Chauvel, J., 1971a, Les échinodermes carpoïdes du Paléozoïque inférieur marocain: Notes et Mémoires du Service Géologique du Maroc, v. 237, p. 49-60.

Chauvel, J., 1971b, Rhopalocystis Ubaghs: un échinoderme éocrinoïde du Trémadocien de l'Anti-Atlas marocain: Mémoires du Bureau de Recherches Géologiques et Minières, v. 73, p. 43-49.

Chauvel, J., 1977, Note complémentaire sur les cystoïdes rhombifères (Echinodermes) de l'Ordovicien marocain: Notes du Service géologique du Maroc, v. 38, p. 115-139.

Chauvel, J., 1978, Compléments sur les échinodermes du Paléozoïque marocain (diploporites, éocrinoïdes, édrioastéroïdés): Notes et Mémoires du Service Géologique du Maroc, v. 272, p. 27-78.

Chauvel, J., and Régnault, S., 1986, Variabilité du genre Rhopalocystis Ubaghs, éocrinoïde du Trémadocien de l'Anti-Atlas marocain: Geobios, v. 19, no. 6 , p. 863-870.

Choubert, G., 1942, Constitution et puissance de la série primaire de l'AntiAtlas: Comptes Rendus de l'Académie Sciences Paris, v. 215, p. 445-447.

Choubert, G., and Termier, H., 1947, Sur la stratigraphie de l'Ordovicien marocain: Compte-rendu sommaire des séances de la Société géologique de France, v. 16, p. 335-337.

Choubert, G., Termier, H., and Termier, G., 1953, Présence du genre Mimocystites Barrande dans l'Ordovicien du Maroc: Notes et Mémoires du Service Géologique du Maroc, v. 117, p. 137-143.

Cocks, L.R.M., and Torsvik, T.H., 2006, European geography in a global context from the Vendian to the end of the Palaeozoic, in Gee, D.G., and Stephenson, R.A., eds., European Lithosphere Dynamics: Geological Society of London, Memoir, v. 32, p. 83-95.

Cripps, A.P., 1990, A new stem-craniate from the Ordovician of Morocco and the search for the sister-group of the Craniata: Zoological Journal of the Linnean Society, v. 100, no. 1, p. 27-71.

Destombes, J., 1962, Stratigraphie et paléogéographie de l'Ordovicien de l'AntiAtlas (Maroc): un essai de synthèse: Bulletin de la Société Géologique de France, v. 4, p. 453-460.

Destombes, J., 1971, L'Ordovicien au Maroc. Essai de synthèse stratigraphique: Mémoires du Bureau de Recherches Géologiques et Minières, v. 73, p. 237-263.

Destombes, J., 1972, Les trilobites du sous-ordre des Phacopina de l'Ordovicien de l'Anti-Atlas (Maroc): Notes et Mémoires du Service Géologique du Maroc, v. 240, p. 1-114.

Destombes, J., 2006, Carte géologique au 1/200 000 de l'Anti-Atlas marocain. Notice explicative. Paléozoïque inférieur: Cambrien moyen et supérieur Ordovicien - Base du Silurien. Feuille Todrha - Maïder: Notes et Mémoires du Service Géologique du Maroc, v. 243, bis, p. 1-58.

Destombes, J., Hollard, H., and Willefert, S., 1985, Lower Palaeozoic rocks of Morocco, in Holland, C.H., ed., Lower Palaeozoic Rocks of the World. v. 4 Lower Palaeozoic Rocks of Northwest and West-Central Africa: Chichester, John Wiley and Sons, p. 91-336.

Donovan, S.K., and Savill, J.J., 1988, Ramseyocrinus (Crinoidea) from the Arenig of Morocco: Journal of Paleontology, v. 62, no. 2, p. 283-285.

Faber, C.L., 1886, Remarks on some fossils of the Cincinnati Group: Journal of the Cincinnati Society of Natural History, v. 9, no. 1, p. 14-20.

Fluegeman, R.H., and Orr, R.W., 1990, Occurrence of Sievertsia (Echinodermata: Cyclocystoidea) from the Middle Devonian of northern Indiana: Journal of Paleontology, v. 64, no. 3, p. 480-482.

Foerste, A.F., 1920, Racine and Cedarville cystids and blastoids with notes on other echinoderms: Ohio Journal of Science, v. 21, no. 2, p. 33-78

Fortey, R.A., Harper, D.A.T., Ingham, J.K., Owen, A.W., and Rushton, A.W.A. 1995, A revision of Ordovician series and stages from the historical type area: Geological Magazine, v. 132, no. 1, p. 15-30.

Gahn, F.J., and Baumiller, T.K., 2010, Evolutionary history of regeneration in crinoids (Echinodermata): Integrative and Comparative Biology, v. 50, no. 4 , p. $514 \mathrm{a}-514 \mathrm{~m}$.

Garwood, R.J., Dunlop, J.A., and Sutton, M.D., 2009, High-fidelity X-ray micro-tomography reconstruction of siderite-hosted Carboniferous arachnids: Biology Letters, v. 5, no. 6, p. 841-844.

Gendry, D., Courville, P., Saucède, T., Laffont, R., and Paris, F., 2013, Contribution of morphometrics to the systematics of the Ordovician genus Neseuretus (Calymenidae, Trilobita) from the Armorican Massif: Journal of Paleontology, v. 87, no. 3, p. 456-471.

Glass, A., Ausich, W.I., and Copper, P., 2003, New cyclocystoid (Phylum Echinodermata) from Anticosti Island, Quebec, and its bearing on cyclocystoid life modes: Journal of Paleontology, v. 77, no. 5, p. 949-957.

Guensburg, T.E., 1988, Systematics, functional morphology, and life modes of Late Ordovician edrioasteroids, Orchard Creek Shale, southern Illinois: Journal of Paleontology, v. 62, no. 1, p. 110-126.

Gutiérrez-Marco, J.C., and García-Bellido, D.C., 2015, Micrometric detail in palaeoscolecid worms from Late Ordovician sandstones of the Tafilal Konservat-Lagerstätte, Morocco: Gondwana Research, v. 28, no. 2, p. $875-881$.
Gutiérrez-Marco, J.C., Destombes, J., Rábano, I., Aceñolaza, G.F., Sarmiento, G.N., and San José, M.A., 2003, El Ordovícico Medio del Anti-Atlas marroquí: paleobiodiversidad, actualización bioestratigráfica y correlación: Geobios, v. 36, no. 2, p. 151-177.

Gutiérrez-Marco, J.C., Sá, A.A., and Rábano, I., 2008, Ordovician time scale in Iberia: Mediterranean and global correlation, in Rozhnov, S.V., ed., Development of Early Paleozoic Biodiversity: Role of Biotic and Abiotic Factors, and Event Correlation: Moscow, KMK Scientific Press, p. 46-49.

Hall, J., 1866, Descriptions of some new species of Crinoidea and other fossils from the lower Silurian strata of the age of the Hudson-River Group and Trenton Limestone: Printed in advance from the Report on State Cabinet of Natural History, Albany, 17 p. [see Hall, J., 1872, Description of new species of Crinoidea and other fossils from strata of the age of the Hudson-River Group and Trenton Limestone: Annual Report on the New York State Museum of Natural History, v. 24, p. 205-224.]

Haude, R., and Thomas, E., 1994, Eleutherozoen (Echinodermata) aus dem Unter-Karbon von Aprath im Bergischen Land, in Hackler, C., Heinrich, A. and Krause, E.-B., eds., Geologie, Paläontologie und Vor- und Frühgeschichte zwischen Lippe und Wupper: Archäologie im Ruhrgebiet, v. 2 , p. $115-132$.

Heaslip, W.G., 1969, A new cyclocystoid (Echinodermata) from Cortland, New York, extends class stratigraphic range to Upper Devonian: Geological Society of America Abstracts with Programs, v. 1, no. 7, p. 96

Hunter, A.W., Lefebvre, B., Nardin, E., Régnault, S., Van Roy, P., and Zamora, S., 2010, Preliminary report on new echinoderm Lagerstätten from the Upper Ordovician of the eastern Anti-Atlas, Morocco, in Harris, L.G., Böttger, S.A., Walker, C.W., and Lesser, M.P., eds., Echinoderms: Durham: London, CRC Publications, Taylor \& Francis Group, p. 23-30.

Jell, P.A., and Jell, J.S., 1999, Crinoids, a blastoid and a cyclocystoid from the Upper Devonian reef complex of the Canning Basin, Western Australia: Memoirs of the Queensland Museum, v. 43, no. 1, p. 201-236.

Kesling, R.V., 1963, Morphology and relationships of Cyclocystoides: University of Michigan Museum of Paleontology, Contributions, v. 18, no. 9 , p. 157-176.

Kesling, R.V., 1966, Cyclocystoids, in Moore, R.C., ed., Treatise on Invertebrate Paleontology, Part U, Echinodermata, v. 3, no. 1, New York and Lawrence, Kansas, Geological Society of America and University of Kansas Press, p. U188-U210.

Kolata, D.R., 1975, Middle Ordovician echinoderms from northern Illinois and southern Wisconsin: Paleontological Society Memoir, v. 7, p. 1-74. [Journal of Paleontology, v. 49, no. 3, supplement].

Kolata, D.R., 1982, Cyclocystoids, in Sprinkle, J., ed., Echinoderm faunas from the Bromide Formation (Middle Ordovician) of Oklahoma: University of Kansas Paleontological Contributions, Monograph, v. 1, p. 309.

Lefebvre, B., 2007, Changes in Late Ordovician (pre-Hirnantian) echinoderm assemblages: palaeoenvironmental and palaeobiogeographical implications: Acta Palaeontologica Sinica, v. 46, suppl., p. 241-248.

Lefebvre, B., and Botting, J.P., 2007, First report of the mitrate Peltocystis cornuta Thoral (Echinodermata, Stylophora) in the Lower Ordovician of central Anti-Atlas (Morocco): Annales de Paléontologie, v. 93, no. 3, p. $183-198$.

Lefebvre, B., and Fatka, O., 2003, Palaeogeographical and palaeoecological aspects of the Cambro-Ordovician radiation of echinoderms in Gondwanan Africa and peri- Gondwanan Europe: Palaeogeography, Palaeoclimatology, Palaeoecology, v. 195, no. 1-2, p. 73-97.

Lefebvre, B., Nardin, E., Hunter, A.W., and Régnault, S., 2007, Les échinodermes de l'Ordovicien supérieur de l'Anti-Atlas (Maroc): biostratigraphie et paléodiversité: Africa Geoscience Review, v. 14, p. 123-148.

Lefebvre, B., Noailles, F., Hunter, A.W., Nardin, E., Régnault, S., Franzin, B., Van Roy, P., and El Hariri, K., 2008, Les niveaux à échinodermes de Bou Nemrou, un gisement à préservation exceptionnelle de l'Ordovicien supérieur du Tafilalt occidental (Maroc): Mésogée, v. 64, p. 7-25.

Lefebvre, B., Noailles, F., Franzin, B., Régnault, S., Nardin, E., Hunter, A.W. Zamora, S., Van Roy, P., El Hariri, K., and Lazreq, N., 2010, Les gisements à échinodermes de l'Ordovicien supérieur de l'Anti-Atlas oriental (Maroc): un patrimoine scientifique exceptionnel à préserver: Bulletin de l'Institut Scientifique Rabat, v. 32, p. 1-17.

Lefebvre, B., Sumrall, C.D., Shroat-Lewis, R.A., Reich, M., Webster, G.D Hunter, A.W., Nardin, E., Rozhnov, S.V., Guensburg, T.E., Touzeau, A., Noailles, F., and Sprinkle, J., 2013, Palaeobiogeography of Ordovician echinoderms, in Harper, D.A.T., and Servais, T., eds., Early Palaeozoic Biogeography and Palaeogeography: Geological Society of London, Memoir, v. 38, p. 173-198.

Lefebvre, B., El Hariri, K., Lerosey-Aubril, R., Servais, T., and Van Roy, P., 2016a, The Fezouata Shale (Lower Ordovician, Anti-Atlas, Morocco): a historical review: Palaeogeography, Palaeoclimatology, Palaeoecology, v. 460 , p. 7-23.

Lefebvre, B., Allaire, N., Guensburg, T.E., Hunter, A.W., Kouraïss, K., Martin, E., Nardin, E., Noailles, F., Pittet, B., Sumrall, C.D., and Zamora, S., 2016b, 
Palaeoecological aspects of the diversification of echinoderms in the Lower Ordovician of central Anti-Atlas, Morocco: Palaeogeography, Palaeoclimatology, Palaeoecology, v. 460, p. 97-121.

Legg, D.A., Garwood, R.J., Dunlop, J.A., and Sutton, M.D., 2012, A taxonomic revision of orthosternous scorpions from the English Coal Measures aided by x-ray micro-tomography (XMT): Palaeontologia Electronica, v. 15, no. $2[14 \mathrm{~A}], 16 \mathrm{p}$.

Le Héron, D.P., 2007, Late Ordovician glacial record of the Anti-Atlas, Morocco: Sedimentary Geology, v. 201, no. 1-2, p. 93-110.

Le Menn, J., and Spjeldnaes, N., 1996, Un nouveau crinoïde Dimerocrinitidae (Camerata, Diplobathrida) de l'Ordovicien supérieur du Maroc: Geobios, v. 29 , no. 3 , p. $341-351$.

Loi, A., Ghienne, J.-F., Dabard, M.P., Paris, F., Botquelen, A., Christ, N., Elaouad-Debbaj, Z., Gorini, A., Vidal, M., Videt, B., and Destombes, J., 2010, The Late Ordovician glacio-eustatic record from a high-latitude storm-dominated shelf succession: The Bou Ingarf section (Anti-Atlas, Southern Morocco): Palaeogeography, Palaeoclimatology, Palaeoecology, v. 296, no. 3-4, p. 332-358.

Männil, R.M., [Mânnil', R.M.] 1983, Nahodki skeletnyh èlementov redkih iglokožih v ordovike i silure Pribaltiki [Findings of rare Ordovician and Silurian echinoderm skeletal elements from the Baltic area], in Hynda, V.A., [Ginda, V.A.] ed., Spravnitel'naâ morfologiâ èvolûziâ i rasprostranenie sovremennyh i vymerših iglokožih [Comparative morphology, evolution and distribution of modern and fossil echinoderms]: L'vov, Gosudarstvennyj prirodovedčeskij muzej AN USSR, p. 51-52.

Marante, A., 2008, Architecture et dynamique des systèmes sédimentaires silicoclastiques sur la «plate-forme géante» nord-gondwanienne: l'Ordovicien moyen de l'Anti-Atlas marocain [Ph.D. thesis]: Bordeaux, Université Michel de Montaigne, $219 \mathrm{p}$.

Martin, E., Lefebvre, B., and Vaucher, R., 2015, Taphonomy of a stylophorandominated assemblage in the Lower Ordovician of Zagora area (central Anti-Atlas, Morocco), in Zamora, S., and Rábano, I., eds., Progress in Echinoderm Palaeobiology: Cuadernos del Museo Geominero, v. 19, p. $95-100$.

Martin, E., Pittet, B., Gutiérrez-Marco, J.C., Vannier, J., El Hariri, K., LeroseyAubril, R., Masrour, M., Nowak, H., Servais, T., Vandenbroucke, T., Van Roy, P., Vaucher, R., and Lefebvre, B., 2016, The Lower Ordovician Fezouata Konservat-Lagerstätte from Morocco: age, environment and evolutionary perspectives: Gondwana Research, v. 34, p. 274-283.

Miller, S.A., 1882, Descriptions of three new orders and four new families, in the class Echinodermata, and eight new species from the Silurian and Devonian formations: Journal of the Cincinnati Society of Natural History, v. 5, no. 4, p. 221-231.

Miller, S.A., and Dyer, C.B., 1878, Contributions to palæontology: Journal of the Cincinnati Society of Natural History, v. 1, no. 1, p. 24-39.

Miller, S.A., and Faber, C.L., 1892, Some new species and new structural parts of fossils: Journal of the Cincinnati Society of Natural History, v. 15, no. 2, p. 79-87.

Miller, S.A., and Gurley, F.E., 1895, Description of new species of Palæozoic Echinodermata: Bulletin of the Illinois State Museum of Natural History, v. 6 , p. 1-62.

Nardin, E., 2007, New occurrence of the Ordovician eocrinoid Cardiocystites: Palaeogeographical and palaeoecological implications: Acta Palaeontologica Polonica, v. 52, no. 1, p. 17-26.

Nardin, E., and Régnault, S., 2015, Palaeoecology of Ascocystites-dominated assemblages (Echinodermata, Blastozoa, Eocrinoidea) from the Upper Ordovician of the Moroccan Anti-Atlas, in Zamora, S., and Rábano, I., eds., Progress in Echinoderm Palaeobiology: Cuadernos del Museo Geominero, v. 19 , p. $109-114$.

Nichols, D., 1969, Echinoderms (fourth edition): London, Hutchinson and Sons, Ltd., 192 p.

Noailles, F., Lefebvre, B., Guensburg, T.E., Hunter, A.W., Nardin, E., Sumrall, C.D., and Zamora, S., 2010, New echinoderm-Lagerstätten from the Lower Ordovician of central Anti-Atlas (Zagora area, Morocco): a Gondwanan perspective of the Great Ordovician Biodiversification Event, in Reich, M., Reitner, J., Roden, V., and Thuy, B., eds., Echinoderm Research: Göttingen, Universitätsverlag, p. 77-78.

Paul, C.R.C., 1982, How much of the record is fossiliferous? in Mamet, B., and Copeland, M.J., eds., North American Paleontological Convention III, Abstracts of papers: Journal of Paleontology, v. 56, no. 2, supplement, p. 20.

Rábano, I., Gutiérrez-Marco, J.C., and García-Bellido, D.C., 2014, A remarkable illaenid trilobite from the Middle Ordovician of Morocco: Bulletin of Geosciences, v. 89, no. 2, p. 365-374.

Rahman, I.A., Adcock, K., and Garwood, R.B., 2012, Virtual fossils: a new resource for science communication in paleontology: Evolution, Education, and Outreach, v. 5, p. 635-641.

Régnault, S., 2007, Présence de l'éocrinoïde Ascocystites Barrande (Echinodermata, Blastozoa) dans l'Ordovicien supérieur (Caradoc) de l'Anti-Atlas (Maroc): premières données: Annales de Paléontologie, v. 93, no. 3, p. 215-227.
Reich, M., and Kutscher, M., 2010, Cyclocystoids (Echinodermata: Echinozoa) from the Silurian of Gotland, Sweden, in Harris, L.G., Böttger, S.A., Walker, C.W., and Lesser, M.P., eds., Echinoderms: Durham: London, CRC Publications, Taylor \& Francis Group, p. 67-70.

Reich, M., and Smith, A.B., 2008, Scotiadiscus nom. nov., a replacement name for Actinodiscus Smith \& Paul, 1982 (Cyclocystoidea), preoccupied by Actinodiscus de Blainville, 1830 (Anthozoa): Paläontologische Zeitschrift, v. 82 , no. 1 , p. $100-101$.

Reich, M., Franzén, C., and Kutscher, M., 2007, Cyclocystoids (Echinodermata: Echinozoa) from the Ordovician of Sweden and Estonia, in Elicki, O., and Schneider, J.W., eds., Fossile Ökosysteme. 77. Jahrestagung der Paläontologischen Gesellschaft. Kurzfassungen der Vorträge und Poster: Wissenschaftliche Mitteilungen, Institut für Geologie, TU Freiberg, v. 36, p. 108.

Ressmeyer, P.F., and Frest, T.J., 1983, Ecology, distribution, and evolutionary history of the "rare" echinoderm class Cyclocystoidea in central North America: Geological Society of America Abstracts with Programs, v. 15, no. 4 , p. 248

Rouault, M., 1851, Mémoire sur le terrain paléozoïque des environs de Rennes: Bulletin de la Société géologique de France ( $2^{\mathrm{e}}$ sér.), v. 8, p. 358-399.

Rowe, F.W.E., 1988, Review of the extant class Concentricycloidea and reinterpretation of the fossil class Cyclocystoidea, in Burke, R.D., Mladenov, P.V., Lambert, P., and Parsley, R.L., eds., Echinoderm Biology: Rotterdam, A. A. Balkema, p. 3-15.

Ruta, M., 1999, A new stylophoran echinoderm, Juliaecarpus milnerorum, from the late Ordovician Upper Ktaoua Formation of Morocco: Bulletin of the Natural History Museum London (Geology), v. 55, p. 47-79.

Salter, J.W., and Billings, E., 1858, On Cyclocystoides, a new genus of Echinodermata from the lower and middle Silurian rocks: Geological Survey of Canada, Figures and Descriptions of Canadian Organic Remains, Decade, v. 3, p. 86-90.

Samuelsson, J., Van Roy, P., and Vecoli, M., 2001, Micropalaeontology of a Moroccan Ordovician deposit yielding soft-bodied organisms showing Ediacara-like preservation: Geobios, v. 34, no. 4, p. 365-373.

Ségaud, E., and Termier, H., 1933, Sur l'Ordovicien du Djebel Tachilla (Maroc Sud-Ouest): Compte-rendu sommaire des séances de la Société géologique de France, v. 3, p. 33.

Sevastopulo, G.D., 2002, Fossil 'lilies of the ocean' and other echinoderms from Carboniferous rocks of Ireland, in John Jackson Memorial Lecture 2002: Occasional Papers in Irish Science and Technology, v. 25, p. 1-15.

Sieverts-Doreck, H., 1951, Über Cyclocystoides Salter \& Billings und eine neue Art aus dem belgischen und rheinischen Devon: Senckenbergiana, v. 32, no. $1-4$, p. $9-30$.

Smith, A.B., and Paul, C.R.C., 1982, Revision of the class Cyclocystoidea (Echinodermata): Philosophical Transactions of the Royal Society of London, B. Biological Sciences, v. 296, no. 1083, p. 577-684.

Smith, A.B., and Wilson, M.A., 1995, A new cyclocystoid (Echinodermata) from the Late Ordovician of Kentucky, U.S.A.: Journal of Paleontology, v. 69 , no. 6 , p. $1186-1187$.

Sprinkle, J., Reich, M., and Lefebvre, B., 2015, Computed tomography (CT) scans of a new Ordovician cyclocystoid from Morocco and its orientation and life mode, in Zamora, S., and Rábano, I., eds., Progress in Echinoderm Palaeobiology: Cuadernos del Museo Geominero, v. 19, p. 163-167.

Sumrall, C.D., 1994, Thecal designs in isorophinid edrioasteroids: Lethaia, v. 26 , no. 4 , p. $289-302$.

Sumrall, C.D., and Zamora, S., 2011, Ordovician edrioasteroids from Morocco: faunal exchanges across the Rheic Ocean: Journal of Systematic Palaeontology, v. 9, no. 3, p. 425-454.

Sutton, M., Rahman, I., and Garwood, R., 2014, Techniques for Virtual Palaeontology: Chichester, John Wiley \& Sons, Ltd., 200 p.

Termier, G., and Termier, H., 1950, Paléontologie marocaine 2(4). Invertébrés de l'Ere Primaire. Annélides, arthropodes, échinodermes, conularides et graptolithes: Notes et Mémoires du Service Géologique du Maroc, v. 79, p. $1-279$.

Termier, H., and Termier, G., 1970, Un échinoderme encroûtant de l'Ashgill (Ordovicien supérieur) du Tafilalt (Sud marocain): Herpetocystis destombesi nov. gen. nov. sp.: Comptes Rendus de l'Académie Sciences Paris, v. 271, p. 1260-1263.

Ubaghs, G., 1963, Rhopalocystis destombesi n. g., n. sp., éocrinoïde de l'Ordovicien inférieur (Trémadocien supérieur) du Sud marocain: Notes et Mémoires du Service Géologique du Maroc, v. 172, p. 25-45.

Van Roy, P., 2006, Non-trilobite arthropods from the Ordovician of Morocco [Ph.D. thesis]: Ghent, Universiteit Gent, 230 p.

Van Roy, P., Orr, P.J., Botting, J.P., Muir, L.A., Vinther, J., Lefebvre, B., El Hariri, K., and Briggs, D.E.G., 2010, Ordovician faunas of Burgess Shale type: Nature, v. 465 , no. 7295 , p. $215-218$.

Van Roy, P., Daley, A.C., and Briggs, D.E.G., 2015, Anomalocaridid trunk limb homology revealed by a giant Ordovician filter-feeder with paired lateral flaps: Nature, v. 522, no. 7554, p. 77-80. 
Videt, B., Paris, F., Rubino, J.-L., Boumendjel, K., Dabard, M.-P., Loi, A., Ghienne, J.-F., Marante, A., and Gorini, A., 2010, Biostratigraphical calibration of third order Ordovician sequences on the northern Gondwana platform: Palaeogeography, Palaeoclimatology, Palaeoecology, v. 296, no. 3-4, 359-375.

Villas, E., Vizcaïno, D., Álvaro, J.J., Destombes, J., and Vennin, E., 2006, Biostratigraphic control of the latest-Ordovician glaciogenic unconformity in Alnif (Eastern Anti-Atlas, Morocco), based on brachiopods: Geobios, v. 39 , no. 5 , p. $727-737$.

Vinther, J., Van Roy, P., and Briggs, D.E.G., 2008, Machaeridians are Palaeozoic armoured annelids: Nature, v. 451, no. 7175, p. 185-188.

Webby, B.D., Cooper, R.A., Bergström, S.M., and Paris, F., 2004, Stratigraphic framework and time slices, in Webby, B.D., Paris, F., Droser, M.L., and Percival, I.G., eds., The Great Ordovician Biodiversification Event: New York, Columbia University Press, p. 41-47.
Wilson, A.E., 1946, Echinodermata of the Ottawa Formation of the OttawaSt. Lawrence Lowland: Canada Department of Mines and Resources, Geological Survey Bulletin, v. 4, p. 1-61.

Wilson, M.A., Palmer, T.J., Guensburg, T.E., Finton, C.D., and Kaufman, L.E., 1992, The development of an Early Ordovician hardground community in response to rapid sea-floor calcite precipitation: Lethaia, v. 25 , no. 1 , p. 19-34.

Zamora, S., Rahman, I.A., and Ausich, W.I., 2015, Palaeogeographic implications of a new iocrinid crinoid (Disparida) from the Ordovician (Darriwilian) of Morocco: PeerJ, v. 3, no. e1450, 19 p., doi: 10.7717/peerj.1450.

Zittel, K.A. von, 1895, Grundzüge der Palæontologie (Palæozoologie): München \& Leipzig, R. Oldenbourg, viii + 971 p.

Accepted 21 February 2017 